\title{
Sanguinarine cytotoxicity on mouse melanoma K1735-M2 cells-Nuclear vs. mitochondrial effects
}

\author{
Teresa L. Serafim ${ }^{a}$, Júlio A.C. Matos ${ }^{a}$, Vilma A. Sardão ${ }^{a}$, Gonçalo C. Pereira ${ }^{a}$, \\ Ana F. Branco ${ }^{a}$, Sandro L. Pereira ${ }^{a}$, Donna Parke ${ }^{c}$, Edward L. Perkins $^{c}$, \\ António J.M. Moreno ${ }^{b}$, Jon Holy ${ }^{d}$, Paulo J. Oliveira ${ }^{a, *}$ \\ ${ }^{a}$ Center for Neurosciences and Cell Biology, Department of Zoology, University of Coimbra, P-3004-517 Coimbra, Portugal \\ ${ }^{\mathrm{b}}$ Institute for Marine Research (IMAR), Department of Zoology, University of Coimbra, Portugal \\ ${ }^{\mathrm{c}}$ Department of Biochemistry and Molecular Biology, University of Minnesota Medical School, Duluth, USA \\ ${ }^{\mathrm{d}}$ Department of Anatomy, Microbiology and Pathology, University of Minnesota Medical School, Duluth, USA
}

\section{A R T I C L E I N F O}

\section{Article history:}

Received 10 June 2008

Accepted 9 July 2008

Keywords:

Sanguinarine

K1735-M2 rat melanoma cells

Liver mitochondria

Mitochondrial physiology

Cell proliferation

Mitochondrial permeability

transition

Bioenergetics

Apoptosis

\begin{abstract}
A B S T R A C T
Sanguinarine (SANG) is an alkaloid recognized to have anti-proliferative activity against various human tumour cell lines. No data is available on the susceptibility of advanced malignant melanoma to SANG, although this disease has a very poor prognosis if not detected in time due to the resistance to conventional chemotherapy. The present work was designed to study the nuclear and mitochondrial involvement in the pro-apoptotic effect of SANG in an invasive mouse melanoma cell line. The results obtained show that SANG is primarily accumulated by the cell nuclei, causing inhibition of cell proliferation and inducing cell death, as confirmed by an increase in sub-G1 peaks. At low concentrations, SANG induces mitochondrial depolarization in a sub-population of melanoma cells, which also generally displayed strong nuclear labelling of phosphorylated histone H2AX. Western blotting revealed an increase in p53, but not Bax protein, in both whole-cell extracts and in mitochondrial fractions. Isolated hepatic mitochondrial fractions revealed that SANG affects the mitochondrial respiratory chain, and has dual effects on mitochondrial calcium loading capacity. We suggest that SANG is able to induce apoptosis in metastatic melanoma cells. The knowledge of mitochondrial vs. nuclear effects of SANG is important in the development of this promising compound for clinical use against aggressive melanoma.
\end{abstract}

(C) 2008 Elsevier Inc. All rights reserved.

\section{Introduction}

Sanguinarine (SANG, 13-methyl-benzodioxolo-[5,6-c]-1,3dioxolo[4,5-i]phenanthridinium) [1,2] is an alkaloid derived from the root of Sanguinaria canadensis and other plants from the Papaveraceae family. SANG is a benzophenanthridine structural homologue of chelerythrine [3]. A positive moiety is present in the aromatic ring of the molecule (Fig. 1).

\footnotetext{
* Corresponding author. Tel.: +351 239 855760; fax: +351 239855789.

E-mail address: pauloliv@ci.uc.pt (P.J. Oliveira).

Abbreviations: ADP, adenosine diphosphate; ATP, adenosine triphosphate; APAF-1, apoptotic protease-activating factor-1; $\mathrm{CH}_{2} \mathrm{DCFDA}$, chloromethyl dichlorodihydrofluorescein diacetate acetyl ester; CsA, Cyclosporin A; DMSO, dimethyl sulfoxide; EM, electron microscopy; FCCP, Carbonyl cyanide $p$-trifluoromethoxyphenylhydrazone; H2AX $\gamma$, gamma-phosphorylated histone H2AX; MPT, mitochondrial permeability transition; mtDNA, mitochondrial DNA; RCR, respiratory control ratio; ROS, reactive oxygen species; RT-PCR, real-time polymerase chain reaction; SANG, sanguinarine; S.E.M., standard error of the mean; TMRM, tetramethylrhodaminemethyl ester; $\mathrm{TPP}^{+}$, tetraphenylphosphonium cation.
}

0006-2952/\$ - see front matter (C) 2008 Elsevier Inc. All rights reserved.

doi:10.1016/j.bcp.2008.07.013 
<smiles>C[n+]1cc2c3c(ccc2c2ccc4cc5c(cc4c21)OCO5)OCO3</smiles>

Fig. 1 - Molecular structure of sanguinarine.

Epidemiological studies have suggested that the use of SANG for oral rinse and toothpaste products effectively suppresses dental plaque formation and decreases gingival inflammation, mainly via its antioxidant, antimicrobial and anti-inflammatory effects [4,5]. Nevertheless, use of SANG in such products has been discontinued because of several reports of leukoplakia, although doubts remain on the role of SANG on the triggering of this condition $[6,7]$.

SANG is known to exert a wide range of biological properties including antimicrobial [8], antifungal [9], antiinflammatory [10] and antineoplastic activity; it has been shown to inhibit a variety of human tumour cell types at micromolar concentrations, without affecting normal cells [11-13]. It also inhibits several enzymes such as lipoxygenase [14], cholinesterase [15], sodium/potassium and calcium ATPases in skeletal muscle $[16,17]$, and alters tubulin assembly [18].

Some examples exist regarding the anti-proliferative activity of SANG. For example, it has been described that SANG causes death of human colon cancer cells [19] and blocks the nucleocytoplasmic trafficking of cyclin D1 and topoisomerase II [20] in breast cancer MCF-7 cells. In another example, SANG was demonstrated to induce the expression of pro-death Bcl-2 proteins including Bax or Bak in immortalized human $\mathrm{HaCaT}$ keratinocytes [21].

The role of mitochondria in drug-induced cell death is well documented $[22,23]$ and several anti-cancer agents are known to cause cell death through interacting with the organelle [24]. Relatively little is known regarding the effects of SANG on isolated mitochondria. Barreto et al. [25] identified complex II as a mitochondrial target for SANG, although only oxygen consumption was used as an experimental end-point. Other reports indicate that SANG causes oxidative stress, mitochondrial depolarization and cytochrome $c$ release $[21,26,27]$.

Phytochemicals with anti-proliferative activity are promising agents against resistant tumours, including melanoma. Advanced melanoma can be highly aggressive, metastatic, and resistant to conventional chemotherapy [28,29]. Hence, there is an urgent need to find novel chemotherapeutics with selective and powerful effects on melanoma.

The objective of the present work is to investigate the effect of low micromolar concentrations of SANG on a mouse metastatic melanoma cell line and determines the role of mitochondria on SANG-induced cytotoxicity. Mouse K1735M2 cells are a very aggressive and invasive form of metastatic melanoma [30,31], which has been used to investigate the potential anti-tumour effect of berberine, another alkaloid with potential to be used as an effective chemotherapeutic on melanoma [32,33]. Data on intact cells were correlated with effects on isolated hepatic mitochondria, and we examined the possibility that SANG may have an inductive effect on the mitochondrial permeability transition pore (MPT pore), a deleterious condition for cells $[34,35]$.

\section{Materials and methods}

\subsection{Reagents}

Sanguinarine chloride was obtained from SIGMA (St. Louis, MO) and dimethyl sulfoxide (DMSO) was used as solvent. The effect of DMSO was tested for all experiment and determined to be negligible. Tetramethylrhodaminemethyl ester (TMRM), Hoechst 33342 and calcein-AM were obtained from Molecular Probes (Invitrogen, Carlsbad, CA). Other compounds, unless specified, were of the highest purity commercially available and were obtained from SIGMA (St. Louis, MO).

\subsection{Animals}

Male Wistar rats (10 weeks) housed at $22 \pm 2{ }^{\circ} \mathrm{C}$ under artificial light for a 12-h light/day cycle with access to water and food ad libitum, were used throughout the experiments. The research procedure was carried out in accordance with the European Requirement for Vertebrate Animal Research.

\subsection{Cell culture}

K1735-M2 mouse melanoma cells (kindly offered by Dr. Lillian Repesh, Department of Anatomy, Microbiology, and Pathology, University of Minnesota Medical School, Duluth) were culture in Dulbecco's modified Eagle's medium (GIBCO, Grand Island, NY) with 10\% Fetal Clone III (FC3; HyClone, Logan, UT) in an atmosphere of $5 \% \mathrm{CO}_{2}$ at $37^{\circ} \mathrm{C}$. $\mathrm{K} 1735-\mathrm{M} 2$ cells are a very aggressive and invasive metastatic melanoma cell line [30,31].

\subsection{Quantification of sanguinarine cell uptake}

To measure drug uptake, K1735-M2 cells were exposed for 150 min with $1.25,2.5,5,10$ and $20 \mu \mathrm{M}$ of SANG. Cells were collected and resuspended in PBS-5\% FC3, and the relative fluorescence intensity measured with a Becton-Dickenson FACScalibur Flow Cytometer (BD Biosciences, San Jose, CA).

\subsection{Measurement of cell proliferation}

Sulforhodamine B assays were conducted to measure the effects of SANG on the proliferation of K1735-M2 cells, essentially as described by Holy et al. [20]. Cells were seeded at a concentration of $1 \times 10^{4}$ cells $/ \mathrm{ml}$ in 48 -well plates, and allowed to recover for 1 day prior to SANG addition. FCCP (carbonyl cyanide 4-(triXuoromethoxy) phenylhydrazone)) was added to cells 30 min before the addition of the alkaloid. Vehicle controls were also performed. After sulforhodamine labelling, absorbance was measured in a spectrophotometer at $540 \mathrm{~nm}$; the amount of dye released is proportional to the number of cells present in the dish, and is a reliable indicator 
of cell proliferation [36]. Values were measured in percentage of time zero (i.e., the cell mass before drug or vehicle treatment).

\subsection{Quantification of cell death}

After treatment with DMSO or SANG for $24 \mathrm{~h}$, both culture media and cells (initially seeded at $2.5 \times 10^{4}$ cells $/ \mathrm{ml}$ ) were collected and saved. Cells were centrifuged and resuspended in PBS containing 5\% FC3. Cells were incubated for $15 \mathrm{~min}$ at $37^{\circ} \mathrm{C}$ with the Live-Dead kit (ethidium homodimer and calcein-AM; Molecular Probes, Eugene, OR). Becton-Dickenson FACSalibur Flow Cytometer was used to measure FL1 (calcein, green) signal and FL3 (ethidium, red) signal. To quantify the red and green-fluorescing cells, cytometry Cell Quest software package was used.

\subsection{Vital epifluorescence imaging of K1735-M2 cells}

Cells were seeded in glass-bottom dishes (P35G-1.5-14-C, MatTek Corporation, Ashland, MA) at a concentration of 1$2 \times 10^{4}$ cells $/ \mathrm{ml}$. Cells were allowed to attach for $24 \mathrm{~h}$ and then treated with SANG or with the vehicle (DMSO) for the desired time.

(a) Detection of SANG accumulation: When SANG accumulation was studied (by using the compound self-fluorescence), cells were visualized under a Nikon Eclipse TE2000U epifluorescence microscope using the fluorescein filter. A short time of exposure was used as SANG selffluorescence decayed rapidly with light exposure. $100 \mathrm{nM}$ TMRM was incubated with cells 30 min before the end of the exposure time.

(b) Labelling with Hoechst 33342, TMRM and calcein-AM: Before the ending the drug exposure time, cells in glassbottom dishes were incubated with TMRM (100 nM), Hoechst $33342(1 \mu \mathrm{g})$ and calcein-AM $(300 \mathrm{nM})$ for $30 \mathrm{~min}$ at $37^{\circ} \mathrm{C}$ in the dark. Due to the very low fluorescence of the probes in the extracellular media, the images were collected without replacing the cell culture media. The images were obtained using a Nikon Eclipse TE2000U epifluorescence microscope.

\subsection{Determination of mitochondrial DNA copy number}

Total genomic nuclear and mtDNA from K1735-M2 cells was isolated using GenElute Mammalian Genomic DNA Miniprep Kit (SIGMA, St. Louis, MO). The GenElute procedure consists in a combination of silica binding with a microspin format. Cells in culture were lysed in a chaotropic salt-containing solution and followed by an addition of ethanol. Washes removed the contaminants and DNA is eluted in $200 \mu$ l of Tris-EDTA solution.

Standard curves were generated from the control DNA sample using serial dilutions. Quantitative real-time PCR using the LightCycler system (Roche Diagnostics, Indianapolis, IN) was prepared the following reaction components: $3.6 \mu l$ water, $0.2 \mu \mathrm{l}$ forward primer $(0.2 \mu \mathrm{M}), 0.2 \mu \mathrm{l}$ reverse primer $(0.2 \mu \mathrm{M})$ and $5.0 \mu$ l LightCyler (Roche Diagnostics, Indianapolis). LightCycler mixture $(9 \mu \mathrm{l})$ was filled in the LightCycler glass capillaries and $1 \mu \mathrm{l}$ of DNA sample ( $2 \mathrm{ng}$ ) was added as PCR template. 5COI and 3COI are mtDNA primers [37] and MuRTGADD45a (ACCCCGATAACGTGGTACTG) and MuGADD45R (TGACCCGCAGGATGTTGATG) are Mouse GADD45 genomic DNA primers that sit in exon3. Capillaries were closed, centrifuged and placed into the LightCycler rotor. The following LightCycler experimental run protocol was used: denaturation program $\left(95^{\circ} \mathrm{C}\right.$ for $30 \mathrm{~s}$ ), amplification and quantification program repeated 50 times $\left(95^{\circ} \mathrm{C}\right.$ for $5 \mathrm{~s}, 60^{\circ} \mathrm{C}$ for $20 \mathrm{~s}, 72^{\circ} \mathrm{C}$ for $20 \mathrm{~s}$ ), melting curve program $\left(95-45-95^{\circ} \mathrm{C}\right.$ with a final heating rate of $0.1^{\circ} \mathrm{C} / \mathrm{s}$ and a continuous fluorescence measurement) and finally a cooling step to $40^{\circ} \mathrm{C}$. The crossing points (CP) for each transcript were mathematically based on the standard curves.

\subsection{Cell cycle analysis}

For cell cycle studies, cells were exposed to different concentrations of SANG for different periods of time. Cells were collected and fixed with cold $70 \%$ ethanol and stored (in $-20{ }^{\circ} \mathrm{C}$ ). Cells were washed and resuspended in PBS-T. Cells were incubated at $37^{\circ} \mathrm{C}$ for $45 \mathrm{~min}$ in $0.5 \mathrm{ml} \mathrm{PBS}$ - T with $20 \mu \mathrm{g} /$ $\mathrm{ml}$ RNase (SIGMA, St. Louis, MO) and then stained with Propidium Iodide (Molecular Probes, Invitrogen, Carlsbad, CA) for $30 \mathrm{~min}$ at $37^{\circ} \mathrm{C}$. Once more the flow cytometer was used, this time for DNA quantification. Using Modfit LT software (Verity Software House, Topsham, ME), the percentage of cells in the different cell cycle phases was determined.

\subsection{Determination of oxidative stress in live cells}

Vital imaging of oxidative stress in K1735-M2 was determined according to the protocol by Sardao et al. [38]. Cells seeded in glass-bottom dishes were incubated with $7.5 \mu \mathrm{M} \mathrm{CM}$ $\mathrm{H}_{2}$ DCFDA (Molecular Probes, Invitrogen, Carlsbad, CA) for $1 \mathrm{~h}$ at $37^{\circ} \mathrm{C}$ in the dark. Media was then replaced by new prewarmed DMEM and cells were returned to the incubator for another hour. Media was then again replaced by $2 \mathrm{ml}$ of Krebs buffer ( $1 \mathrm{mM} \mathrm{CaCl}_{2}$; $132 \mathrm{mM} \mathrm{NaCl} ; 4 \mathrm{mM} \mathrm{KCl} ; 1.2 \mathrm{mM} \mathrm{Na}_{2} \mathrm{HPO}_{4}$; $1.4 \mathrm{mM} \mathrm{MgCl}_{2} ; 6 \mathrm{mM}$ glucose; $10 \mathrm{mM}$ HEPES, $\mathrm{pH}$ 7.4). Cells were observed by epifluorescence microscopy using a Nikon Eclipse TE2000U microscope (fluorescein filter) and images were obtained using Metamorph software (Universal Imaging, Downington, PA).

\subsection{Collection of total and mitochondrial extracts from K1735-M2 cells}

To obtain total cellular extracts, K1735-M2 cells were harvested by trypsinization (with Trypsin-EDTA, Gibco-Invitrogen, NY) and washed once with PBS, after treatment with SANG. Floating cells were also collected and combined with adherent cells. In order to collect the total amount of cells, two centrifugation steps were performed for $5 \mathrm{~min}$ at $1000 \times \mathrm{g}$. Cellular pellet was resuspended in collecting buffer $(20 \mathrm{mM}$ HEPES/NaOH, pH 7.5, $250 \mathrm{mM}$ Sucrose, $10 \mathrm{mM} \mathrm{KCl,} 2 \mathrm{mM}$ $\mathrm{MgCl}_{2}, 1 \mathrm{mM}$ EDTA) supplemented with $2 \mathrm{mM}$ dithiothreitol (DTT), $100 \mu \mathrm{M}$ phenylmethylsulfonyl fluoride (PMSF) and a protease inhibitor cocktail (containing $1 \mu \mathrm{g} / \mathrm{ml}$ of leupeptin, antipain, chymostatin and pepstatin A) and ruptured by 30 
passages through a 27-gauge needle. The cell suspension was then rapidly frozen/thawed 3 times in liquid nitrogen and kept at $-80^{\circ} \mathrm{C}$ until used. For subcellular fractionation, cells were harvested as described above and resuspended in homogenization buffer (250 $\mathrm{mM}$ sucrose, $20 \mathrm{mM} \mathrm{K}^{+}$HEPES $\mathrm{pH} 7.5$, $10 \mathrm{mM} \mathrm{KCl}, 1.5 \mathrm{mM} \mathrm{MgCl}, 0.1 \mathrm{mM}$ EDTA, $1 \mathrm{mM} \mathrm{EGTA)}$ supplemented with $1 \mathrm{mM}$ DTT, $100 \mu \mathrm{M}$ PMSF and protease inhibitor cocktail (containing $1 \mu \mathrm{g} / \mathrm{ml}$ of leupeptin, antipain, chymostatin and pepstatin A). Cell homogenization was performed in a Potter-Elvehjem homogenizer with Teflon pestle. The homogenate was subjected to sedimentation at $220 \times g$ during $5 \mathrm{~min}$ at $4{ }^{\circ} \mathrm{C}$. The supernatant, containing mitochondrial fraction, was centrifuged again at $14,000 \times 9$ during $10 \mathrm{~min}$ at $4{ }^{\circ} \mathrm{C}$. The pellet, corresponding to the mitochondrial fraction was resuspended in $50 \mu$ l of homogenization buffer. Samples were stored at $-80^{\circ} \mathrm{C}$ until used. Protein contents were determined by the Bradford method.

\subsection{Western blot analysis}

Alterations in proteins expression were analyzed by Western blot. After the treatment of K1735-M2 mouse melanoma cells with SANG, total and mitochondrial extracts were collected. After denaturation at $95^{\circ} \mathrm{C}$ for $5 \mathrm{~min}$ in a Laemmli buffer (BioRad, Hercules, CA), equivalent amount of proteins (50 $\mu \mathrm{g}$ ) were separated by electrophoresis on 8 or $12 \%$ SDS-polyacrylamide gels (SDS-PAGE) (Bio-Rad, Hercules, CA) and electrophoretically transferred to a polyvinylidene difluoride (PVDF) membrane (Bio-Rad, Hercules, CA). After blocking with $5 \%$ milk in TBST (50 mM Tris-HCl, pH 8; $154 \mathrm{mM} \mathrm{NaCl}$ and 0.1\% Tween 20) for $2 \mathrm{~h}$ at room temperature, membranes were incubated, overnight at $4{ }^{\circ} \mathrm{C}$, with the antibodies directed against to the denaturated form of p53 (1:200) (Santa Cruz Biotechnology, CA), Bax (1:5000) (Cell Signalling, Piscataway, NJ) and APAF-1 (1:500) (Cell Signalling, Piscataway, NJ). Membranes were further incubated with the alkaline phosphatase-conjugated secondary antibodies, for $1 \mathrm{~h}$ at room temperature. Membranes were reacted with the ECF detection system (Amersham, UK) and read with the Versa Doc imaging system (BioRad, Hercules, CA). Densities of each band were calculated with Quantity One Software (Bio-Rad, Hercules, CA). Membranes were also stained with Ponceau reagent to confirm equal protein loading in each lane.

\subsection{Immunocytochemistry for phosphorylated H2AX histone (H2AX $)$}

K1735-M2s grown on glass coverslips were treated with $2 \mu \mathrm{M}$ SANG; controls received an equivalent amount of DMSO (vehicle only). After a $16 \mathrm{~h}$ exposure, cells were loaded with Mitotracker Red, 1:10,000 dilution from a $1 \mathrm{mM}$ stock solution (Molecular Probes, Invitrogen, Carlsbad, CA) which was added directly to the culture medium for $45 \mathrm{~min}$. Cells were then fixed in $2 \%$ paraformaldehyde in PBS for $5 \mathrm{~min}$ at room temperature, and subsequently transferred to ice-cold methanol and stored in a freezer overnight. After rehydration in PBS$\mathrm{T}$, coverslips were blocked with $1 \%$ powdered milk in PBS-T for $30 \mathrm{~min}$ at $37^{\circ} \mathrm{C}$, and incubated in a mouse monoclonal antibody to phosphorylated histone H2AX (H2AXgamma; Upstate, Cell Signalling, Piscataway, NJ) for $1 \mathrm{~h}$ at $37^{\circ} \mathrm{C}$.
Following three PBS-T washes, cells were incubated in goatanti-mouse IgG conjugated to fluorescein (1:10,000, Jackson Immunoresearch) (Cell Signalling, Piscataway, NJ) and Hoechst $33258(5 \mu \mathrm{g} / \mathrm{ml})$ for $1 \mathrm{~h}$ at $37^{\circ} \mathrm{C}$, washed again in PBS-T, and mounted in anti-fade medium ( $90 \%$ glycerol, $10 \%$ CAPS buffer, $\mathrm{pH}$ 9.0, and 0.1\% phenylenediamine).

\subsection{Caspase-like activity assay}

Total cellular extracts were collected as described above and protein contents were assayed using the Bradford method. To measure caspase 3 and 9-like activity, aliquots of cell extracts containing $25 \mu \mathrm{g}$ (for caspase 3) or $50 \mu \mathrm{g}$ (for caspase 9) were incubated in a reaction buffer containing 25 mM HEPES ( $\mathrm{pH}$ 7.4), $10 \%$ sucrose; $10 \mathrm{mM} \mathrm{DTT}, 0.1 \%$ CHAPS and $100 \mu \mathrm{M}$ caspase substrate (Ac-DEVD-pNA for caspase 3 or Ac-LEHD-pNA for caspase 9, purchased from Calbiochem, NJ, USA) for $2 \mathrm{~h}$ at $37^{\circ} \mathrm{C}$. Caspase-like activities were determined by following the detection of the chromophore $p$-nitroanilide after cleavage from the labelled substrate Ac-DEVD-p-nitroanilide or AcLEHD- $p$-nitroanilide. The method was calibrated with know concentrations of $p$-nitroanilide (purchased from Calbiochem, NJ, USA).

\subsection{Isolation of rat liver mitochondria}

Mitochondria were isolated from the livers of male Wistar rats as previously described [32]. Homogenization medium containing $250 \mathrm{mM}$ sucrose, $10 \mathrm{mM}$ HEPES ( $\mathrm{pH} 7.4$ ), 1 mM EGTA, and $0.1 \%$ BSA lipid-free was used. EGTA and BSA were omitted from the final washing medium, adjusted at $\mathrm{pH}$ 7.2. Mitochondrial protein was determined by the Biuret method using BSA as a standard. The mitochondrial suspension was kept on ice during experiments, which were carried out after a $30 \mathrm{~min}$ recovery period and within $5 \mathrm{~h}$.

\subsection{Oxygen consumption}

Oxygen consumption of isolated liver mitochondria was measured using a Clark-type oxygen electrode connected to a suitable recorder in a $1 \mathrm{ml}$ thermostated, water-jacketed, closed chamber with magnetic stirring, at $30^{\circ} \mathrm{C}$. The standard respiratory medium consisted of $135 \mathrm{mM}$ sucrose, $65 \mathrm{mM} \mathrm{KCl}$, $2.5 \mathrm{mM} \mathrm{MgCl}_{2}, 5 \mathrm{mM} \mathrm{KH}_{2} \mathrm{PO}_{4}, 5 \mathrm{mM}$ HEPES ( $\mathrm{pH}$ 7.2). Mitochondria were suspended at a concentration of $1.5 \mathrm{mg} / \mathrm{mL}$. Respiration was started by adding $5 \mathrm{mM}$ glutamate/malate or $5 \mathrm{mM}$ succinate together with $3 \mathrm{mM}$ rotenone. ADP (125 nmol) was used to induce state 3. State 4 was measured as the respiratory rate after ADP phosphorylation. Oligomycin $(1 \mu \mathrm{g})$ and FCCP $(1 \mu \mathrm{M})$ were also added to the system in order to inhibit passive flux through the ATP synthase and to uncouple respiration, respectively. SANG was pre-incubated with mitochondria in the reaction medium for $2 \mathrm{~min}$ before the addition of the respiratory substrate.

\subsection{Mitochondrial transmembrane potential}

The mitochondrial transmembrane potential $(\Delta \Psi)$ was indirectly estimated by the mitochondrial accumulation of the lipophilic cation tetraphenylphosphonium $\left(\mathrm{TPP}^{+}\right)$as detected 
by using a $\mathrm{TPP}^{+}$selective electrode in combination with an $\mathrm{Ag} / \mathrm{AgCl}$-saturated reference electrode. Both the $\mathrm{TPP}^{+}$electrode and the reference electrode were inserted into an open vessel with magnetic stirring and were connected to a $\mathrm{pH}$ meter (Jenway, Model 3305). The signals were fed to a potentiometric recorder (Kipp \& Zonen, Model BD 121). No correction was made for the "passive" binding of TPP ${ }^{+}$to the mitochondrial membranes, since the purpose of the experiments was to show relative changes in potentials rather than absolute values. Mitochondrial protein $(1.5 \mathrm{mg})$ was suspended under constant stirring in $1 \mathrm{~mL}$ of reaction medium

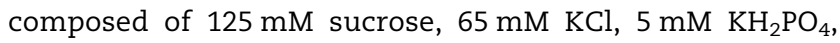
$2.5 \mathrm{mM} \mathrm{MgCl}_{2}$ and $5 \mathrm{mM}$ HEPES (pH 7.4, $30{ }^{\circ} \mathrm{C}$ ), supplemented with $3 \mu \mathrm{M} \mathrm{TPP}^{+}$.

Mitochondria were energized with $10 \mathrm{mM}$ glutamate/ malate or $10 \mathrm{mM}$ succinate plus $3 \mu \mathrm{M}$ rotenone. SANG was added prior to mitochondrial protein. ADP $(125 \mathrm{nmol})$ was added to initiate phosphorylation. Absolute values for membrane potential (in millivolts) were determined as previously described [32], assuming Nernst distribution of the ion across the membrane electrode. A matrix volume of $1.1 \mu \mathrm{l} / \mathrm{mg}$ protein was assumed.

\subsection{Mitochondrial swelling}

Mitochondrial osmotic volume changes were measured by the apparent absorbance at $540 \mathrm{~nm}$ with a JASCO V-560 spectrophotometer. The assays were performed in $2 \mathrm{ml}$ of the reaction media (200 mM sucrose, $10 \mathrm{mM}$ Tris-MOPS ( $\mathrm{pH} 7.4$ ),

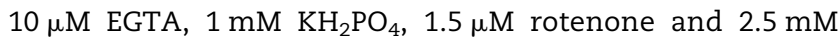
succinate) and with $1.5 \mathrm{mg}$ protein with constant stirring, at $30{ }^{\circ} \mathrm{C}$. Calcium $(20 \mu \mathrm{M})$ was added to the system after $60 \mathrm{~s}$ in order to start mitochondrial swelling. Cyclosporin A $(1 \mu \mathrm{M})$ was added to the mitochondrial preparation before the addition of calcium to inhibit the MPT. SANG was incubated with the mitochondrial fraction for $2 \mathrm{~min}$ in reaction medium.

\subsection{Mitochondrial calcium loading}

Extramitochondrial free calcium was assayed by using the hexapotassium salt of the fluorescence probe Calcium Green 5-N (100 nM) (Molecular Probes, Invitrogen, Carlsbad, CA) as previous described [32]. Briefly, liver mitochondria (0.4 mg) were resuspended in $2 \mathrm{ml}$ of buffer containing $200 \mathrm{mM}$ sucrose, $10 \mathrm{mM}$ Tris, $10 \mu \mathrm{M}$ EGTA (to complex basal calcium), $1 \mathrm{mM} \mathrm{KH}_{2} \mathrm{PO}_{4}, 2 \mu \mathrm{M}$ rotenone, and $4 \mathrm{mM}$ succinate. Fluorescence was continuously recorded in a water-jacketed cuvette holder at $30^{\circ} \mathrm{C}$ using a PerkinElmer LS-55 fluorescence spectrometer with excitation and emission wavelengths of 506 and $531 \mathrm{~nm}$, respectively. Slits used were $5 \mathrm{~nm}$ for both excitation and emission wavelengths.

\subsection{Mitochondrial ATPase activity}

First, the activity of mitochondrial ATPase was evaluated thorough the variations of $\mathrm{pH}$ occurring during ATP synthesis, as previously described [32]. Decrease of $\mathrm{pH}$ due to the hydrolysis of ATP was monitored polarographically with an electrode of $\mathrm{pH}$ connected to a suitable recorder in $1 \mathrm{ml}$ thermostated, water-jacketed, opened chamber with magnetic stirring, at $30{ }^{\circ} \mathrm{C}$. Mitochondria ( $1.5 \mathrm{mg}$ protein) were incubated in $1 \mathrm{ml}$ reaction media ( $125 \mathrm{mM}$ sucrose, $65 \mathrm{mM} \mathrm{KCl}$, $2.5 \mathrm{mM} \mathrm{MgCl}_{2}, 5 \mathrm{mM} \mathrm{KH}_{2} \mathrm{PO}_{4}$ ). Reaction was initiated by the addition of $3 \mathrm{mM}$ ATP. Oligomycin was used as a selective inhibitor of ATP synthase (Fo unit), and completely abolished proton consumption. SANG was pre-incubated with the mitochondrial fraction in reaction medium for $2 \mathrm{~min}$ before ATP addiction. Known concentrations of $\mathrm{KOH}$ were used to calibrate the system. To confirm the results, ATP-induced generation of transmembrane potential $(\Delta \Psi)$ was measured by using a $\mathrm{TPP}^{+}$selective electrode as described in the measurement of mitochondrial transmembrane potential. Mitochondria (1.5 mg protein) were incubated in $1 \mathrm{ml}$ of reaction media (125 mM sucrose, $65 \mathrm{mM} \mathrm{KCl,} 2.5 \mathrm{mM} \mathrm{MgCl}_{2}, 5 \mathrm{mM} \mathrm{KH}_{2} \mathrm{PO}_{4}$, $5 \mathrm{mM}$ HEPES) pH 7.4 at $30^{\circ} \mathrm{C}$. The media was supplemented with $3 \mu \mathrm{M} \mathrm{TPP}^{+}$and $3 \mu \mathrm{M}$ rotenone. Reaction was started by $3 \mathrm{mM}$ ATP. Oligomycin was used as a selective inhibitor of ATP synthase (Fo unit). SANG was pre-incubated with the mitochondrial fraction in reaction medium for $2 \mathrm{~min}$ before ATP addition.

\subsection{Statistical analysis}

All obtained values were expressed as means \pm S.E.M. and compared by one-way ANOVA with Bonferroni multiple comparisons post-test. A value of $p<0.05$ was considered statistically significant. Data was analyzed by using GraphPad Prism 4.0 (GraphPad Software).

\section{Results \\ 3.1. Effect of sanguinarine in K1735-M2 cell line proliferation}

In order to investigate the effects of SANG on cell proliferation and cell death, K1735-M2 rat cells were incubated in the absence and presence of increasing concentrations of the drug $(2,4$ and $8 \mu \mathrm{M})$ for $12,24,36$ and $48 \mathrm{~h}$. In Fig. 2, panel $\mathrm{A}$, the survival curve shows that SANG has a dose/time-dependent effect inhibiting K1735-M2 cell proliferation. The inhibitory effect on cell proliferation is more visible after $12 \mathrm{~h}$ of incubation with SANG. After $48 \mathrm{~h}$ of incubation, $8 \mu \mathrm{M}$ SANG has a profound effect on cell proliferation, most likely because of induction of cell death as the corresponding line is below control levels. Panel B is the same experiment but with the extra addition of the mitochondrial uncoupler FCCP. Data shows that FCCP synergistically increases the effect of $4 \mu \mathrm{M}$ SANG. By visualizing mitochondrial TMRM accumulation after incubation with the same concentration of FCCP, no signal was detected, revealing that the concentration of protonophore is effective depolarizing mitochondria in situ (data not shown). Also interesting is the fact that FCCP, per se, was not able to decrease cell mass during the full time frame of the experiments. A third trial was performed to confirm cell death induced by SANG. When measuring cell death by flow cytometry, a significant difference was observed for the highest concentration tested $(8 \mu \mathrm{M})$, which caused more than $20 \%$ of cell death (Fig. 2, panel C). 

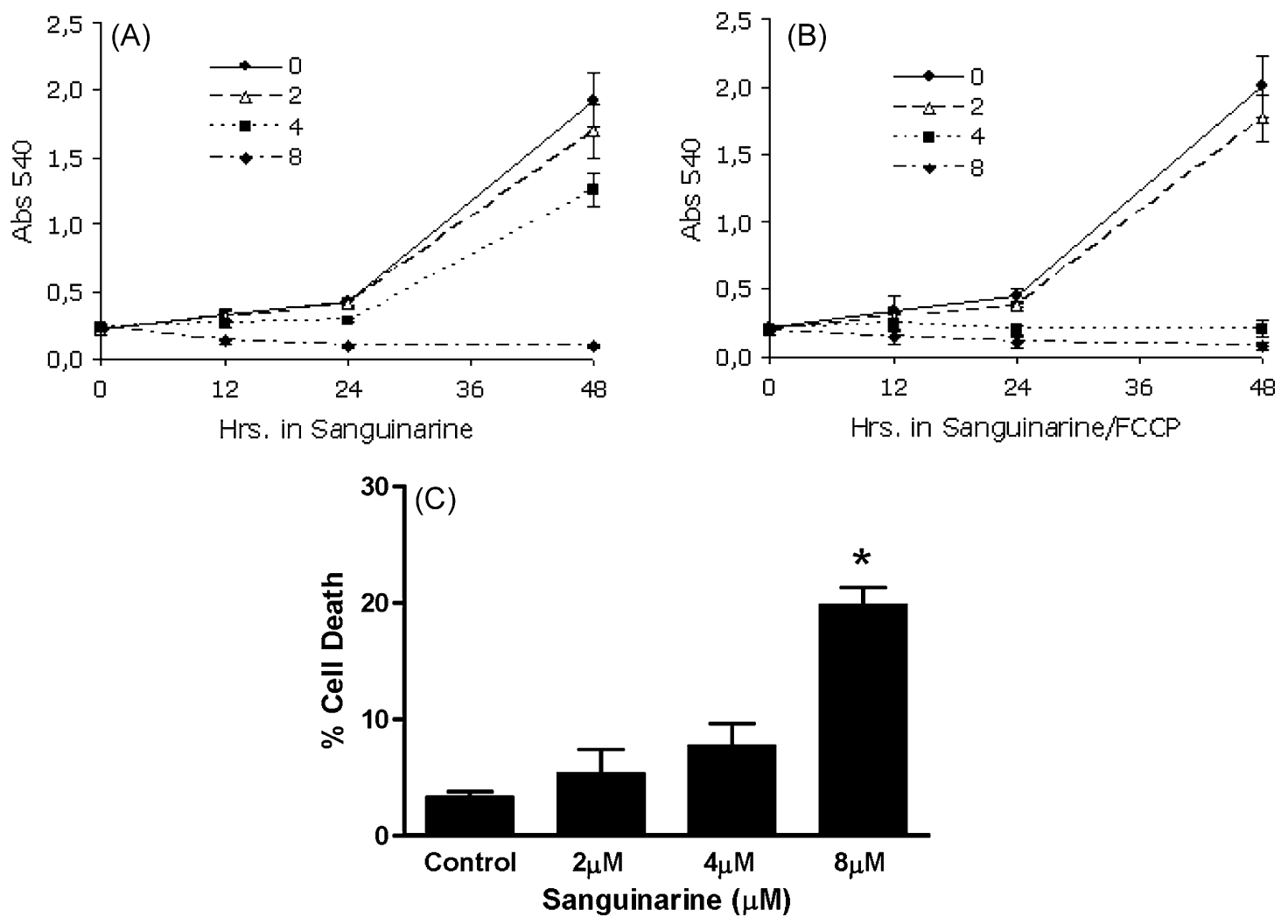

Fig. 2 - Inhibition of cell proliferation and induction of cell death by SANG. (A) Inhibition of cell proliferation by SANG as measured by using the sulforhodamine B assay. Data in the ordinate represent the absorbance of the dye, which is proportional to the amount of cells. Data are means \pm S.E.M. of three independent experiments. (B) As in (A), except that cells were previously incubated with $10 \mu \mathrm{M}$ FCCP for $30 \mathrm{~min}$ before adding SANG. The two molecules were present throughout the entire time frame. Data are means \pm S.E.M. of three independent experiments. (C) Determination of cell death after incubating cells with SANG for $\mathbf{2 4} \mathrm{h}$. Ethidium homodimer and calcein-AM were used as a tool to measure cell death by flow cytometry. Ethidium homodimer-positive, calcein-negative cells were considered necrotic. ${ }^{*} p<0.05$ vs. control. Data are means \pm S.E.M. of three independent experiments.

\subsection{Sanguinarine preferably accumulates in K1735-M2 cells nuclei}

In order to assess the intracellular site for SANG accumulation, K1735-M2 cells were incubated with $4 \mu \mathrm{M}$ SANG for $3 \mathrm{~h}$. Intracellular accumulation of the drug was identified by epifluorescence microscopy as SANG exhibits self-fluorescence [20]. TMRM, a cationic fluorescent probe that accumulates in mitochondria was used to assess the colocalization of the alkaloid and TMRM. The set of images of Fig. 3, upper panel, clearly shows that SANG (green fluorescence) is accumulated by the cell nuclei at a greater level than by mitochondria, this despite the molecule having a positive charge (Fig. 1). In the absence of TMRM, SANG was also not significantly detected in extra-nuclear spaces. Next, SANG intracellular accumulation was quantified by flow cytometry; the lower panel of Fig. 3 reveals that the relative fluorescence increases directly with the increasing SANG concentrations even for concentrations much higher than the ones used in most experiments.
3.3. Sanguinarine induces morphologic changes and mitochondrial depolarization in K1735-M2 cells

Cells pre-treated with SANG were incubated with TMRM (mitochondria), Hoechst 33342 (nuclei) and calcein-AM (cell viability) for $30 \mathrm{~min}$ at $37^{\circ} \mathrm{C}$. Fig. 4 shows several images obtained by epifluorescence. Panels A-D show a control group, with cells showing $70-80 \%$ confluence (A), a vast majority of cells maintaining viability (B), normal nuclear morphology (C) and normal mitochondrial polarization (D). By treating cells with $8 \mu \mathrm{M}$ SANG for $24 \mathrm{~h}$, most cells round up and detach (E), although most still maintain membrane integrity (F) and present abnormal nuclei, with clear signs of condensed chromatin (G). Also, the majority of cells exhibit mitochondrial depolarization $(\mathrm{H})$. A higher magnification of cells treated with $4 \mu \mathrm{M}$ SANG for $24 \mathrm{~h}$ shows that two distinct populations of cells co-exist. Although by phase contrast, cells have mostly a normal appearance $(\mathrm{K})$, some are completely depolarized (L), not showing any TMRM labelling. In contrast, control cells (I, J) display a normal appearance and TMRM mitochondrial labelling. Because of these mitochondrial effects, some 

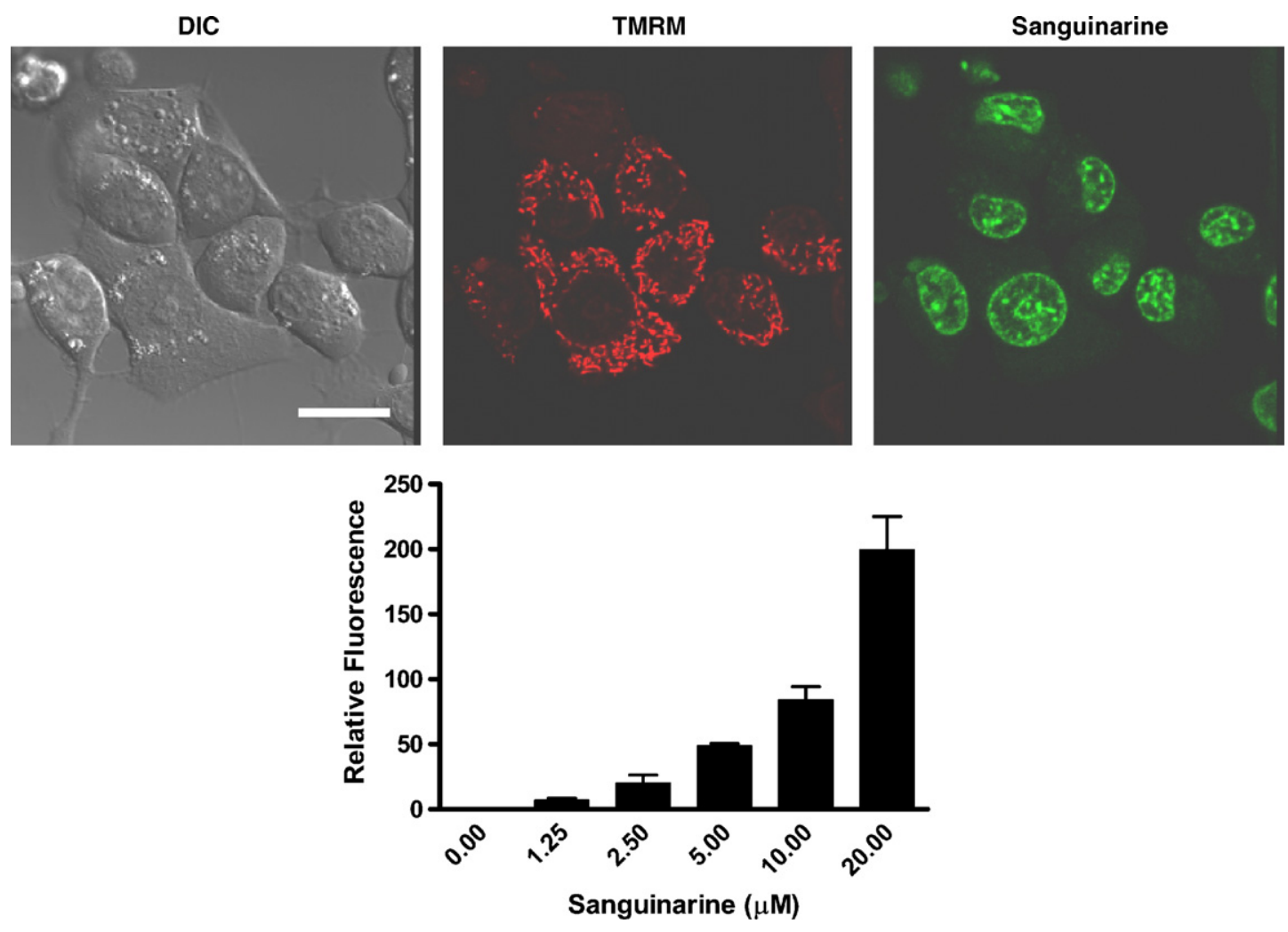

Fig. 3 - Nuclear accumulation of SANG. Upper panel, epifluorescence microscopy of K1735-M2 cells treated with $4 \mu$ M SANG for $3 \mathrm{~h}$. Cells were also co-incubated with $100 \mathrm{nM}$ TMRM (red) which accumulates in polarized mitochondria. An image obtained by differential interference contrast is also shown. White bar represents $15 \mu \mathrm{m}$. Lower panel, SANG accumulation as quantified by flow cytometry. Cells were exposed for $150 \mathrm{~min}$ with 1.25, 2.5, 5, 10 and $20 \mu \mathrm{M}$ SANG. Data are means \pm S.E.M. of three independent experiments.

selected concentrations of SANG were also used to investigate if mtDNA copy number is altered with treatment for $24 \mathrm{~h}$. In fact, no significant alterations in mtDNA were detected (M) for any of the concentrations studied.

\subsection{Sanguinarine-induced mitochondrial depolarization is not associated with oxidative stress}

In order to evaluate whether cells with depolarized mitochondria have increased oxidative stress, co-labelling of $4 \mu \mathrm{M}$ SANG-treated cells with TMRM and the redox-sensitive probe CM- $\mathrm{H}_{2}$ DCFDA was performed after 6 and $24 \mathrm{~h}$ of treatment (Fig. 5). As described above, SANG shows a time-dependent effect on mitochondrial membrane potential, with a general mild depolarization observed after $6 \mathrm{~h}$ and an "all-or-nothing" effect for $24 \mathrm{~h}$. In the two time-points studied, no significant increase in cell fluorescence due to oxidative stress was observed, showing no direct correlation between mitochondrial depolarization and oxidative stress. The same protocol confirmed that berberine, an alkaloid similar to SANG caused an increase in cell oxidative stress (data not shown and [32]). To confirm the absence of oxidative stress in the mechanism of SANG-induced toxicity, we also incubated K1735-M2 cells with n-acetylcysteine (NAC) and SANG and could not find any protection afforded by NAC for 24 or $48 \mathrm{~h}$ of treatment (data not shown).

\subsection{Sanguinarine does not cause significant effects on the K1735-M2 cycle}

It has been described that SANG arrests the cell cycle of several cancer cell lines $[12,39]$ but no information was available regarding melanoma, with the exception of a single study [13]. Fig. 6 describes the data obtained by evaluating cell cycle alterations induced by SANG on K1735-M2 cells. The most noticeable result is an increase in the sub-G1 peak in a dose and time-dependent manner. Although for $24 \mathrm{~h}$ of incubation time no significant differences are found, an increase in subG1 peaks occurs for 48 and $72 \mathrm{~h}$. As consequence, the number of cells in G1, S or G2 phases of the cell cycle decrease accordingly, which is more severe for the highest SANG concentration used and for higher exposure times. Of particular interest is the decrease of cells in S phase observed for $24 \mathrm{~h}$ for all SANG concentrations tested and the decrease in the number of cells in G1 phase observed for $72 \mathrm{~h}$.

\subsection{Sanguinarine activates caspase 3 and 9}

By using a colorimetric method, an increase in caspase-like activity was investigated in extracts from cells treated with SANG for 6 and $24 \mathrm{~h}$. The data in Fig. 7 shows that for $6 \mathrm{~h}$ of treatment, $4 \mu \mathrm{M}$ SANG causes an increase for caspase 3 and 9like activity. Treatment of cells with $8 \mu \mathrm{M}$ resulted into a large 

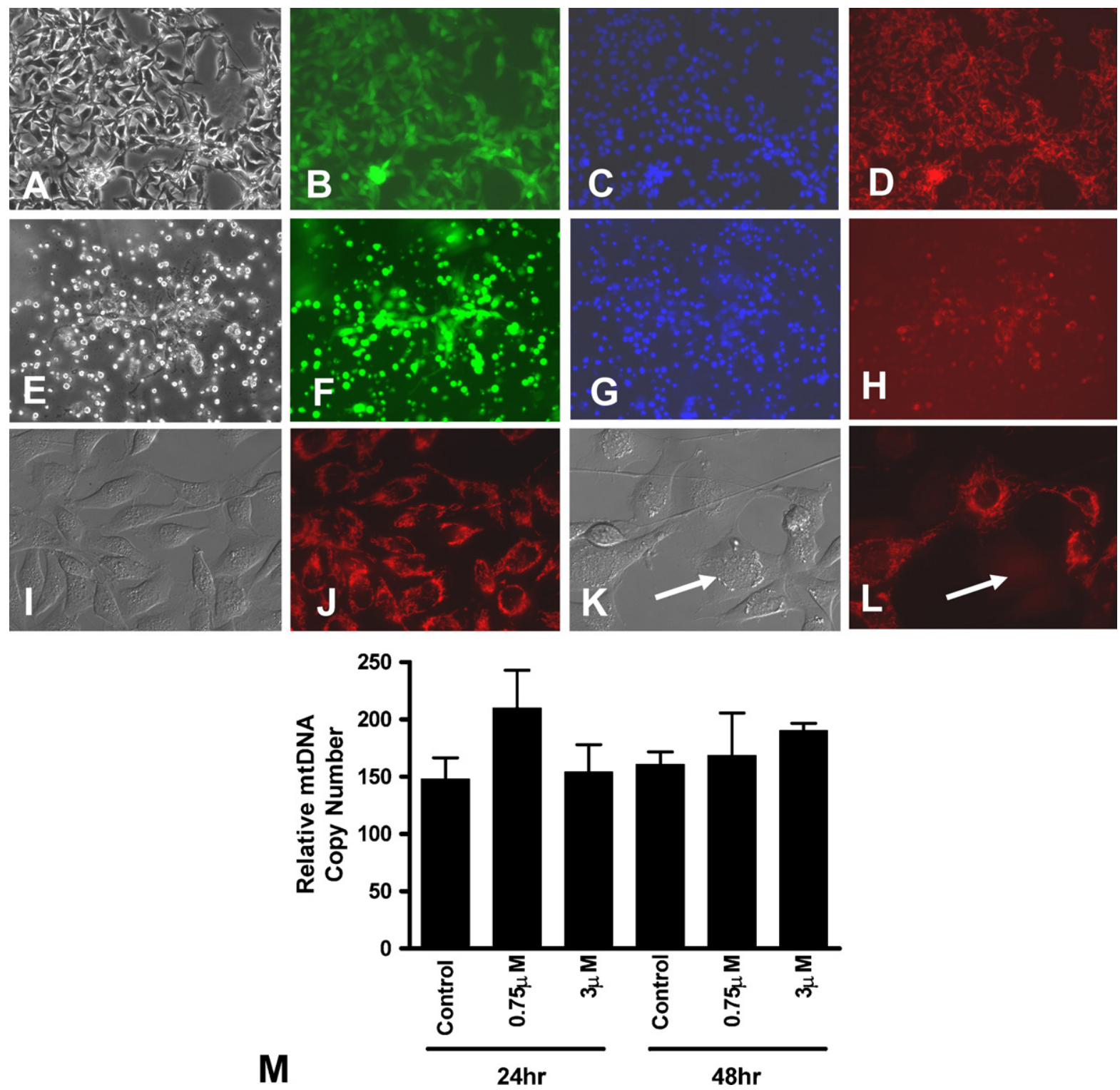

Fig. 4 - Vital imaging of K1735-M2 cells treated with SANG. Cells were incubated with TMRM (100 nM), Hoechst 33342 (1 $\mu$ g) and calcein-AM (300 $\mathrm{nM}$ ) for $30 \mathrm{~min}$ at $37^{\circ} \mathrm{C}$. Panels A-D: Control cells treated for $24 \mathrm{~h}$ with the vehicle DMSO ((A) phase contrast, (B) calcein-AM, (C) Hoechst, (D) TMRM). Panels E-H: Cells treated with $8 \mu$ M SANG for $24 \mathrm{~h}$ ((A) phase contrast, (B) calcein-AM, (C) Hoechst, (D) TMRM). Panels I and J: Control cells treated for $24 \mathrm{~h}$ with the vehicle ((I) 600× DIC, (J) TMRM). Panels $\mathrm{K}$ and L: Cells treated with $4 \mu \mathrm{M}$ SAN for $24 \mathrm{~h}$. Notice the cell with the white arrow which although showing normal morphology, has no mitochondrial TMRM accumulation. Panel M: Quantification of mitochondrial DNA copy number by RTPCR as described in Section 2.

increase of caspase 3-like activity (more than 4-fold increase, data not shown), although a clear loss of cell mass was determined. For $24 \mathrm{~h}$ incubation, no significant alteration of caspase 9 activity was observed for the concentrations tested while $4 \mu \mathrm{M}$ SANG resulted into an increase of caspase 3-like activity (Fig. 7).

\subsection{Role of Bax and p53 on sanguinarine-induced cytotoxicity}

For the data obtained regarding SANG-induced mitochondrial depolarization, one possible explanation would be that SANG causes DNA damage, which is followed by p53 activation and increased Bax expression. By its turn, Bax is recognized to induce mitochondrial dysfunction upon apoptotic stimuli [40]. By performing Western blotting on total cell extracts, an increase in the protein p53 was indeed found (Fig. 8). The density of the band increased in a dose-dependent manner but had no correspondence in an increase in Bax or APAF-1 concentration in the same samples. When analysing mitochondrial fractions obtained from the same cells, the same trend of results was found, meaning that increased mitochondrial p53 but not Bax translocation occurs (Fig. 8). The lack of Bax up-regulation in the mechanism of SANG-induced 

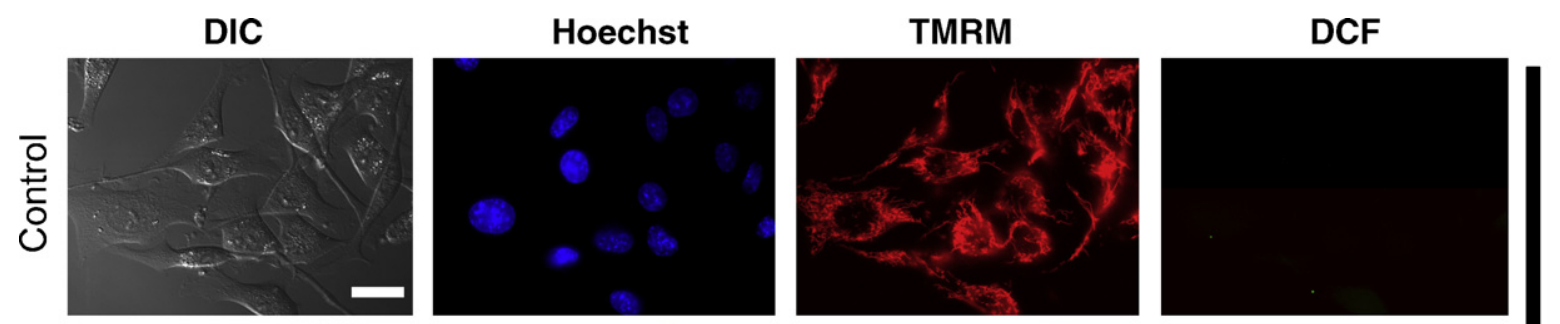

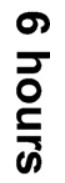
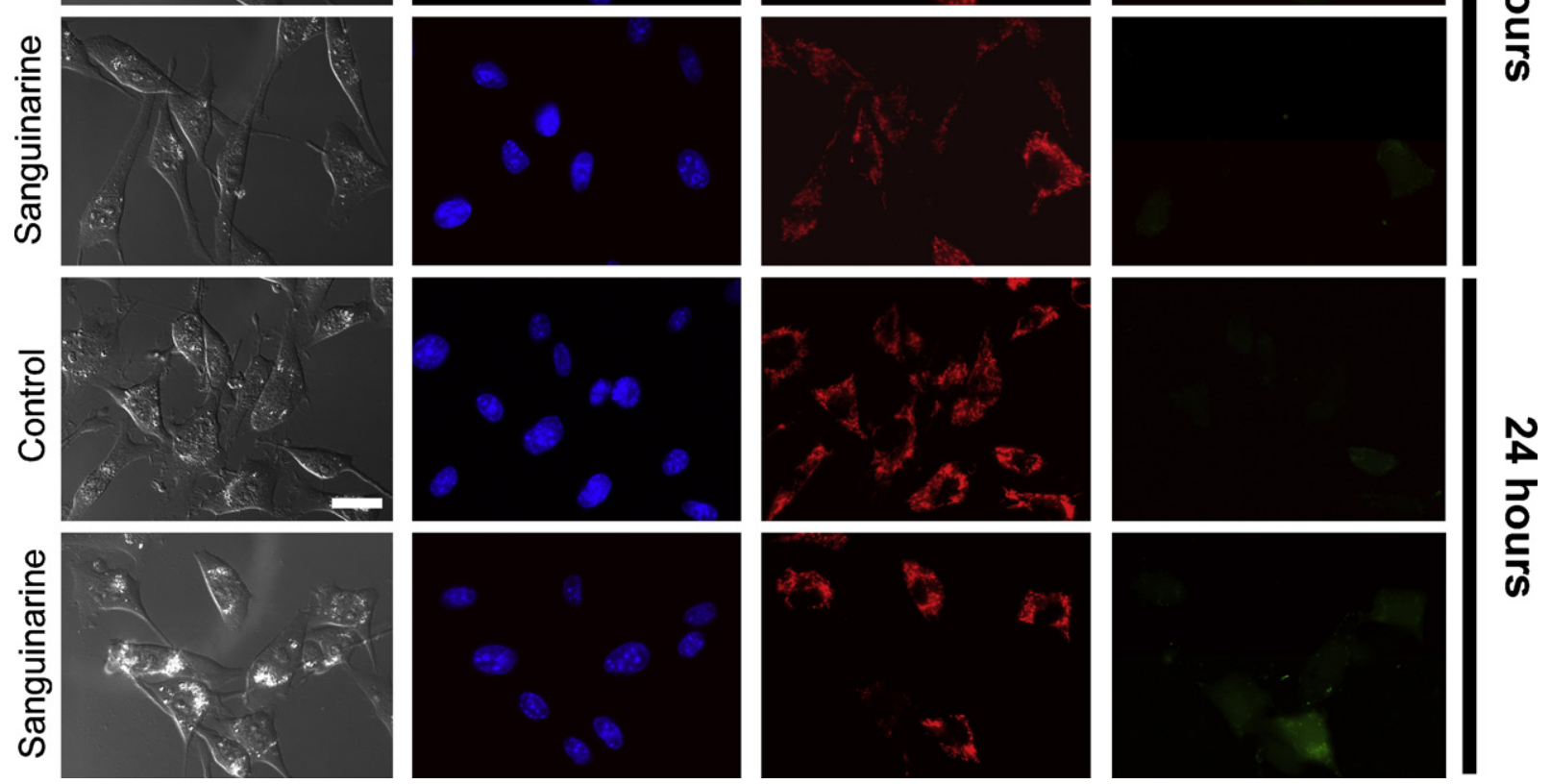

Fig. 5 - SANG causes mitochondrial depolarization but does not generate free radicals when incubated with K1735-M2 cells. Cells were incubated with $4 \mu \mathrm{M}$ SANG for 6 or $24 \mathrm{~h}$. $45 \mathrm{~min}$ before the end of the incubation period, the fluorescent probes TMRM (red, mitochondria), Hoechst (blue, nuclei) and CM-H2DCFDA (green, oxidative stress) were added to the cell suspension and cells were imaged with a Nikon Eclipse 3000 epifluorescence microscope. Notice that a sub-set of cells still have polarized mitochondria after $24 \mathrm{~h}$ of incubation (last row, TMRM column), although no intracellular oxidative stress is evident.

cytotoxicity was confirmed by performing sulforhodamine B assays with two compounds that are supposed to inhibit the mitochondrial role of Bax on the induction of cell death. The two compounds used were Bax-inhibiting peptide V5 and Baxchannel blocker $[41,42]$. No protection was afforded by any of the blockers (data not shown).

\subsection{Does DNA damage correlate with mitochondrial} depolarization induced by sanguinarine?

To test whether SANG resulted in nuclear DNA damage, SANG and control cells were labelled with an antibody to phosphorylated histone $\mathrm{H} 2 \mathrm{AX}(\mathrm{H} 2 \mathrm{AX} \gamma)$, which is a recognized marker for DNA damage [43]. An increase in nuclear fluorescence in the SANG-treated group was readily observed by immunofluorescence (Fig. 9 upper panel and lower panel, left graph). Cells were double-labelled with MitoTracker Red and the level of nuclear fluorescence of H2AX $\gamma$ was measured in cells with polarized vs. cells with depolarized mitochondria. As seen in Fig. 9, lower panel, right graph, cells with low mitochondrial polarization possessed higher levels of nuclear H2AXy labelling, demonstrating a relation of both events. It is worth mentioning that vital imaging with TMRM resulted into an all-or-nothing effect while using MitoTracker Red with fixed cells always resulted in cells with low basal fluorescence vs. cells with high, mitochondrialderived, fluorescence.

\subsection{Mitochondrial effects on isolated mitochondrial fractions-respiration, mitochondrial transmembrane potential and ATPase}

The effect of SANG on isolated mitochondrial fractions was evaluated by comparing oxygen consumption and the generation of the transmembrane electric potential $(\Delta \Psi)$ in the absence and presence of the drug. Tables 1 and 2 show the results obtained when hepatic mitochondria were energized by using glutamate-malate and succinate, respectively. Significant statistical differences are visible for the higher concentrations of SANG used for both complex I- and complex II-sustained respiration, although it is clear that complex Isustained respiration is more affected. In general, SANG stimulates state 4 and state 4 plus oligomycin respiration and inhibits uncoupled and state 3 respiration. The largest inhibition is actually seen for uncoupled respiration (a.p. $75 \%$ decrease). 

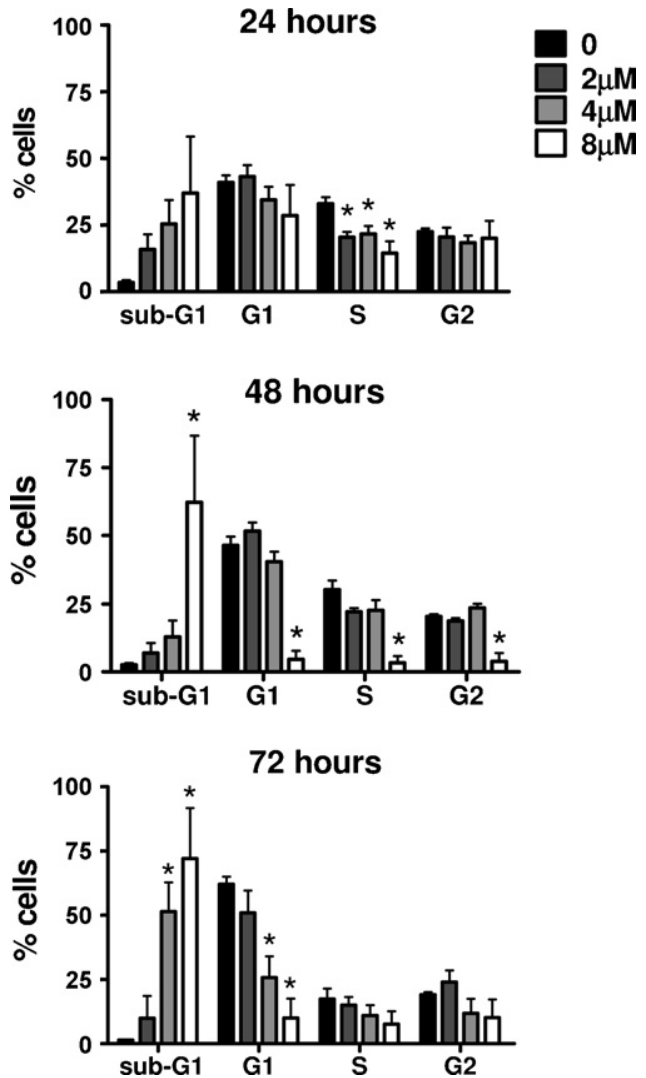

Fig. 6 - Effect of SANG on K1735-M2 cell cycle and sub-G1 phases. Nuclear binding of propidium iodide was used to determine cell cycle phase. Cells were incubated with SANG for 24, 48 and $72 \mathrm{~h}$, as described in Section 2. Results are represented as $\%$ total cells. Data are means \pm S.E.M. of three independent experiments. ${ }^{*} p<0.05$ vs. control for the same time point.

Variations in mitochondrial $\Delta \Psi$ resulting from energization and ADP phosphorylation were also measured in control and SANG-treated mitochondria. Results obtained in mitochondria energized with glutamate/malate and succinate are shown in Tables 3 and 4 respectively. No statistically significant differences were observed for any concentration of SANG tested.

Another experiment on isolated liver mitochondria regarded the possible effect of SANG on the ATP synthase. The first approach to test a possible effect rely on the fact that ATP hydrolysis by freeze-thawed mitochondria lead to an increase of protons on the reaction medium. The second approach is based on the generation of transmembrane potential of isolated intact mitochondrial fractions in the presence of ATP and with inhibited respiration. In this particular case, the ATP synthase acts as an ATPase, pumping matrix protons to the mitochondrial inter-membrane space and consuming ATP in the process. Table 5 shows that only one of the methods yielded a statistically significant result, with the highest SANG concentration showing a slight but significant decrease in the rate of proton production.

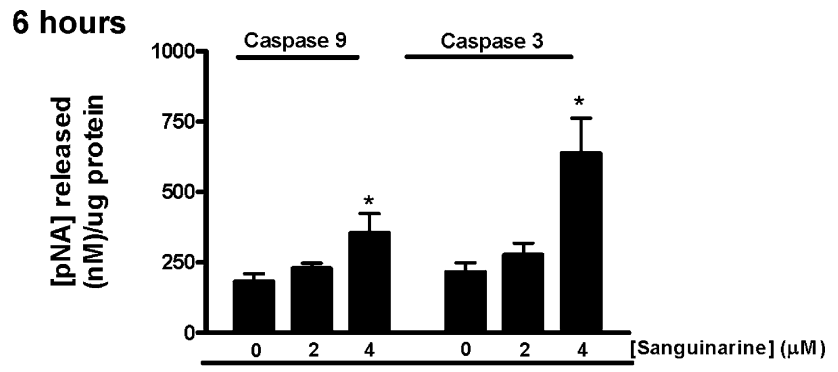

24 hours

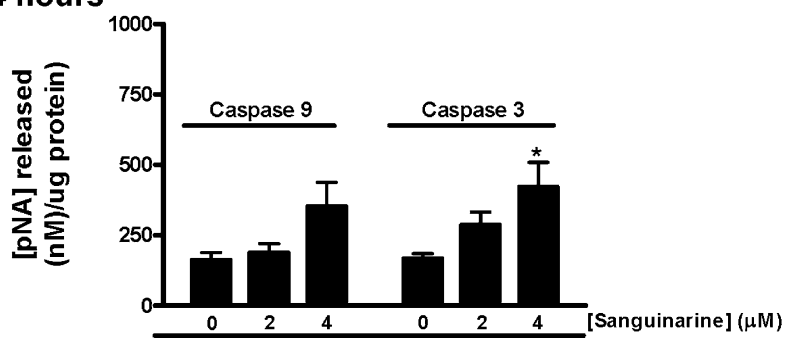

Fig. 7 - Caspase 3 and 9-like activity in K1735-M2 cells treated with SANG. Cells were treated as described in Section 2 with SANG for 6 and $24 \mathrm{~h}$. For higher SANG concentrations, it was not possible to obtain enough protein to conduct all experiments. Data are means \pm S.E.M. of five independent experiments. ${ }^{*} p<0.05$ vs. control for the same time point.

3.10. Sanguinarine effects on the mitochondrial permeability transition

One of the effects of MPT pore opening is mitochondrial water influx which causes mitochondrial swelling. The effect of SANG on calcium-induced mitochondrial swelling was studied by measuring the changes in the suspension absorbance at $540 \mathrm{~nm}$ in a sucrose-based media. Table 6 shows the

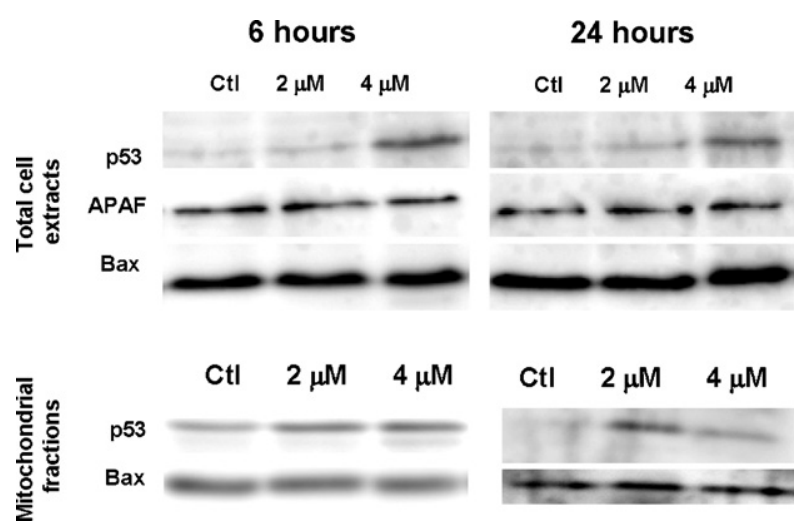

Fig. 8 - Detection by Western blotting of p53, Bax, APAF-1 in total fractions and p53 and Bax in mitochondrial extracts from K1735-M2 cells. Equal protein loading in each lane was confirmed by Ponceau labelling. Cells were incubated with 2 and $4 \mu \mathrm{M}$ SANG for 6 and $24 \mathrm{~h}$ and total extracts and mitochondrial fractions were collected as described. The results are representative of 3-5 separate experiments. 


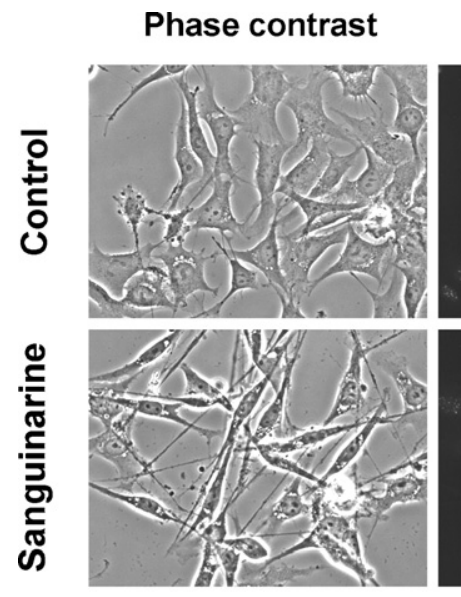

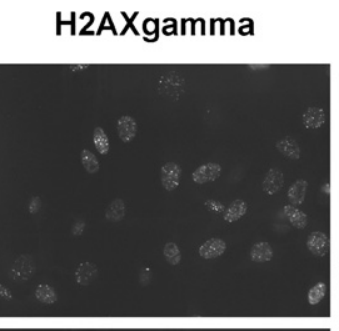

MitoTracker Red
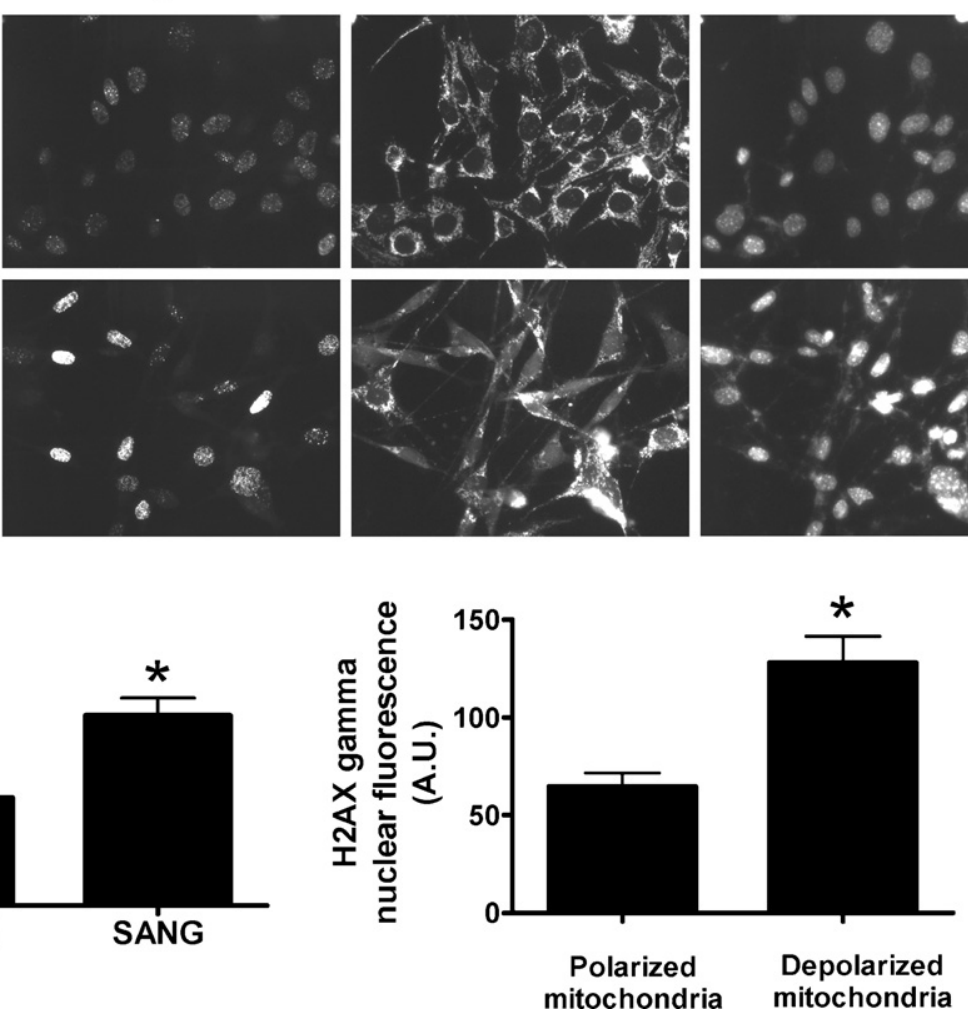

Fig. 9 - Relationship between SANG-induced mitochondrial depolarization and H2AX $\gamma$. Upper panel, epifluorescence microscopy of control and SANG-treated ( $2 \mu \mathrm{M}$ SANG for $16 \mathrm{~h}$ ) K1735-M2 cells. The panels represent phase contrast, MitoTracker Red and nuclear H2AX $\gamma$ and Hoechst labelling. Lower panel, left graph, quantification of nuclear H2AX $\gamma$ fluorescence in control and SANG-treated cells. Lower panel, right graph, quantification of nuclear H2AX $\gamma$ fluorescence in cells with polarized vs. cells with depolarized mitochondria. The latter group included cells without specific mitochondrial MitoTracker Red labelling. Data are means \pm S.E.M., of multiple independent experiments. ${ }^{*} p<0.05$ vs. other experimental group.

\section{Table 1 - Effects of SANG on glutamate-malate-energized mitochondria}

\begin{tabular}{|c|c|c|c|c|c|c|c|}
\hline Protein $(\mathrm{nmol} / \mathrm{mg})$ & State 3 & State 4 & Voligo & Vfccp & RCR & $\mathrm{ADP} / \mathrm{O}$ & Vfccp/Voligo \\
\hline Control & $\begin{aligned} 83.0 & \pm 9.6 \\
100 & \pm 0.0 \%\end{aligned}$ & $\begin{aligned} 7.3 & \pm 2.6 \\
100 & \pm 0.0 \%\end{aligned}$ & $\begin{array}{c}5.4 \pm 2.2 \\
100 \pm 0.0 \%\end{array}$ & $\begin{aligned} 90.0 & \pm 13.0 \\
100 & \pm 0.0 \%\end{aligned}$ & $\begin{aligned} 18.0 & \pm 5.1 \\
100 & \pm 0.0 \%\end{aligned}$ & $\begin{array}{c}2.7 \pm 0.22 \\
100 \pm 0.0 \%\end{array}$ & $\begin{aligned} 38.0 & \pm 16.0 \\
100 & \pm 0.0 \%\end{aligned}$ \\
\hline 0.7 & $\begin{array}{l}79.0 \pm 7.7 \\
97.0 \pm 2.7 \%\end{array}$ & $\begin{array}{c}8.9 \pm 3.5 \\
131.0 \pm 44.0 \%\end{array}$ & $\begin{array}{c}6.7 \pm 3.2 \\
111.0 \pm 23.0 \%\end{array}$ & $\begin{array}{l}71.0 \pm 19.0 \\
74.2 \pm 13.0 \%\end{array}$ & $\begin{array}{c}20.0 \pm 9.8 \\
111.0 \pm 37.0 \%\end{array}$ & $\begin{aligned} 2.9 & \pm 0.18 \\
110.0 & \pm 4.2 \%\end{aligned}$ & $\begin{array}{l}29.0 \pm 11.0 \\
76.0 \pm 20.0 \%\end{array}$ \\
\hline 1.3 & $\begin{array}{l}64.0 \pm 13.0 \\
75.0 \pm 9.9 \%\end{array}$ & $\begin{array}{c}9.3 \pm 2.3 \\
167.0 \pm 50.0 \%\end{array}$ & $\begin{aligned} 6.8 & \pm 2.4 \\
179.0 & \pm 71.0 \%\end{aligned}$ & $\begin{array}{l}63.0 \pm 21.0 \\
66.0 \pm 15.0 \%\end{array}$ & $\begin{aligned} 8.6 & \pm 2.4 \\
57.0 & \pm 13.0 \%\end{aligned}$ & $\begin{array}{c}3.1 \pm 0.21 \\
117.0 \pm 11.0 \%\end{array}$ & $\begin{array}{l}23.2 \pm 16.0 \\
81.3 \pm 47.0 \%\end{array}$ \\
\hline 2.7 & $\begin{array}{l}58.0 \pm 17.0 \\
67.0 \pm 16.0 \%\end{array}$ & $\begin{array}{c}13.0 \pm 3.2 \\
252.0 \pm 75.0 \%^{*}\end{array}$ & $\begin{aligned} 10.0 & \pm 3.3 \\
302.0 & \pm 131.0 \%\end{aligned}$ & $\begin{array}{l}48.0 \pm 15.0 \\
51.0 \pm 12.0 \%\end{array}$ & $\begin{array}{c}6.3 \pm 3.1 \\
42.0 \pm 17.0 \%\end{array}$ & $\begin{array}{c}3.5 \pm 0.45 \\
129.0 \pm 13.0 \%\end{array}$ & $\begin{array}{c}8.8 \pm 4.4 \\
30.0 \pm 10.0 \%\end{array}$ \\
\hline 5.3 & $\begin{array}{l}41.0 \pm 10.0 \\
48.0 \pm 9.9 \%\end{array}$ & $\begin{array}{c}14.0 \pm 2.7 \\
250.0 \pm 56 \%\end{array}$ & $\begin{array}{c}11.0 \pm 2.9 \\
320.0 \pm 120 \%\end{array}$ & $\begin{array}{l}26.0 \pm 8.0 \\
29.0 \pm 6.8 \%\end{array}$ & $\begin{array}{c}3.6 \pm 1.2 \\
24.0 \pm 6.0 \%^{*}\end{array}$ & $\begin{aligned} 3.5 & \pm 0.4 \\
128.0 & \pm 12 \%^{*}\end{aligned}$ & $\begin{array}{c}3.0 \pm 1.0 \\
15.0 \pm 4.5 \%^{*}\end{array}$ \\
\hline
\end{tabular}

Mitochondria $(1.5 \mathrm{mg})$ were incubated in $1 \mathrm{ml}$ respiration media at $30^{\circ} \mathrm{C}$ as described above. State 4 was measured in the presence of $5 \mathrm{mM}$ glutamate/malate. ADP $(125 \mathrm{nmol})$ was added to induce state 3 respiration. Oligomycin $(1 \mu \mathrm{g})$ and FCCP $(1 \mu \mathrm{M})$ were also added to the system in order to inhibit passive proton flux through the ATP synthase and to uncouple respiration. The RCR is defined as the ratio between state 3 and state 4 respiration. The ADP/O was calculated as the number of nmol ADP phosphorylated per nano-atoms oxygen consumed during ADP phosphorylation. Respiration rates are expressed in natms $\mathrm{O} / \mathrm{minute} / \mathrm{mg}$ protein and also as the percentage of control. Data are means \pm S.E.M. of 5-6 different preparations.

$p<0.05$ vs. control. 
Table 2 - Effects of SANG on succinate-energized mitochondria

\begin{tabular}{|c|c|c|c|c|c|c|c|}
\hline Protein (nmol/mg) & State 3 & State 4 & Voligo & Vfccp & RCR & $\mathrm{ADP} / \mathrm{O}$ & Vfccp/Voligo \\
\hline \multirow[t]{2}{*}{ Control } & $85.2 \pm 4.0$ & $20.7 \pm 3.8$ & $16.5 \pm 3.8$ & $147.3 \pm 5.7$ & $5.3 \pm 1.1$ & $1.7 \pm 0.1$ & $12.4 \pm 3.2$ \\
\hline & $100.0 \pm 0.0 \%$ & $100.0 \pm 0.0 \%$ & $100.0 \pm 0.0 \%$ & $100.0 \pm 0.0 \%$ & $100.0 \pm 0.0 \%$ & $100.0 \pm 0.0 \%$ & $100.0 \pm 0.0 \%$ \\
\hline \multirow[t]{2}{*}{0.7} & $96.4 \pm 5.3$ & $27.3 \pm 4.3$ & $20.7 \pm 4.4$ & $149.8 \pm 19.3$ & $4.1 \pm 0.6$ & $1.6 \pm 0.1$ & $12.1 \pm 4.2$ \\
\hline & $113.1 \pm 6.3 \%$ & $147.8 \pm 22.1 \%$ & $135.4 \pm 31.2 \%$ & $141.4 \pm 11.0 \%$ & $84.0 \pm 9.9 \%$ & $95.3 \pm 2.5 \%$ & $97.0 \pm 28.6 \%$ \\
\hline \multirow[t]{2}{*}{1.3} & $88.0 \pm 7.6$ & $26.5 \pm 5.9$ & $20.0 \pm 5.2$ & $125.2 \pm 29.1$ & $6.0 \pm 2.8$ & $2.0 \pm 0.4$ & $17.3 \pm 9.9$ \\
\hline & $104.6 \pm 9.7 \%$ & $138.4 \pm 33 \%$ & $131.1 \pm 36.3 \%$ & $83.6 \pm 18.3 \%$ & $114.7 \pm 39.8 \%$ & $115.2 \pm 25.0 \%$ & $138.1 \pm 73.9 \%$ \\
\hline \multirow[t]{2}{*}{2.7} & $82.1 \pm 15.8$ & $28.2 \pm 4.1$ & $20.5 \pm 4.1$ & $96.2 \pm 24.6$ & $3.2 \pm 0.8$ & $1.7 \pm 0.3$ & $71.4 \pm 3.3$ \\
\hline & $94.2 \pm 16.7 \%$ & $156.6 \pm 18.2 \%$ & $123.4 \pm 4.9 \%$ & $63.3 \pm 15.2 \%$ & $65.5 \pm 13.2 \%$ & $102.9 \pm 17.4 \%$ & $53.3 \pm 13.1 \%$ \\
\hline \multirow[t]{2}{*}{5.3} & $75.3 \pm 13.5$ & $31.0 \pm 5.8$ & $24.2 \pm 5.0$ & $58.0 \pm 14.1$ & $2.8 \pm 0.7$ & $1.7 \pm 0.3$ & $3.1 \pm 1.0$ \\
\hline & $86.1 \pm 13.2 \%$ & $170.1 \pm 24.0 \%^{*}$ & $151.7 \pm 15.8 \%$ & $39.0 \pm 9.1 \%^{*}$ & $55.6 \pm 9.1 \%^{*}$ & $102.1 \pm 17.2 \%$ & $29.4 \pm 9.1 \% *$ \\
\hline
\end{tabular}

Mitochondria $(1.5 \mathrm{mg})$ were incubated in $1 \mathrm{ml}$ respiration media at $30{ }^{\circ} \mathrm{C}$ as described above. State 4 was measured in the presence of $5 \mathrm{mM}$ succinate plus rotenone. ADP $(125 \mathrm{nmol})$ was added to induce state 3 respiration. Oligomycin $(1 \mu \mathrm{g})$ and FCCP $(1 \mu \mathrm{M})$ were also added to the system in order to inhibit passive proton flux through the ATP synthase and to uncouple respiration. The RCR is defined as the ratio between state 3 and state 4 respiration. The ADP/O was calculated as the number of nmol ADP phosphorylated by nano-atoms oxygen consumed during ADP phosphorylation. The ADP/O was calculated as the number of nmol ADP phosphorylated per nano-atoms oxygen consumed during ADP phosphorylation. Respiration rates are expressed in natms O/minute/mg protein and also as the percentage of control. Data are means \pm S.E.M. of 5-6 different preparations.

$p<0.05$ vs. control.

Table 3 - Effects of SANG on glutamate/malate-energized mitochondria

\begin{tabular}{|c|c|c|c|}
\hline Protein (nmol/mg) & $\Delta \Psi(-\mathrm{mV})$ & ADP depolarization $(-\mathrm{mV})$ & Lag phase (s) \\
\hline \multirow[t]{2}{*}{ Control } & $215.9 \pm 2.3$ & $27.6 \pm 2.0$ & $27.2 \pm 2.8$ \\
\hline & $100 \pm 0.0 \%$ & $100 \pm 0.0 \%$ & $100 \pm 0.0 \%$ \\
\hline \multirow[t]{2}{*}{0.7} & $213.2 \pm 3.8$ & $27.14 \pm 2.23$ & $34.2 \pm 3.5$ \\
\hline & $98.5 \pm 0.7 \%$ & $98.3 \pm 23.0 \%$ & $165.4 \pm 3.8 \%$ \\
\hline \multirow[t]{2}{*}{1.3} & $215.3 \pm 4.1$ & $24.89 \pm 2.20$ & $33 \pm 2.1$ \\
\hline & $99.4 \pm 0.7 \%$ & $91.4 \pm 2.8 \%$ & $120.6 \pm 20.5 \%$ \\
\hline \multirow[t]{2}{*}{2.7} & $210.3 \pm 1.7$ & $22.7 \pm 2.4$ & $33.6 \pm 4.2$ \\
\hline & $97.1 \pm 0.5 \%$ & $87.5 \pm 0.7 \%$ & $123.3 \pm 3.8 \%$ \\
\hline \multirow[t]{2}{*}{5.3} & $205.3 \pm 2.7$ & $16.2 \pm 2.5$ & $29.4 \pm 2.6$ \\
\hline & $94.9 \pm 0.9 \%$ & $68.4 \pm 12.3 \%$ & $102.9 \pm 2.9 \%$ \\
\hline
\end{tabular}

swelling rate and amplitude after calcium addition. The data shows that a significant difference is obtained only for a high SANG concentration ( $14.4 \mathrm{nmol} / \mathrm{mg}$ protein). Cyclosporin A was able to inhibit SANG-induced mitochondrial swelling.

We also measured mitochondrial calcium accumulation by using the fluorescent probes Calcium Green 5-N. Shortly after an increase in probe fluorescence due to calcium addition (Fig. 10), fluorescence decreased in all conditions tested, indication of mitochondrial calcium uptake. Interestingly, SANG showed a mixed effect regarding calcium loading capacity. For lower concentrations, SANG actually decreases calcium loading capacity (lowers the time of calcium retention), while for the highest concentration tested $(5 \mathrm{nmol} / \mathrm{mg}$ protein), SANG actually increased calcium retention, this without any effect on the $\Delta \Psi$ (Table 4$)$. The mixed effect on mitochondrial calcium accumulation was confirmed by following $\Delta \Psi$ variations associated with calcium uptake and MPT pore induction. In fact, we also confirmed that for lower concentrations, SANG stimulates calcium-induced $\Delta \Psi$ depo- larization, while for higher concentrations the MPT induction is similar to control (data not shown).

\section{Discussion}

Several plant extracts containing sanguinarine (SANG) as their active compound have been used in traditional Chinese and North American traditional medicine for centuries due to their wide range of pharmacological effects [44]. A search in the literature clearly indicates that traditional medicine is growing in interest due to the discovery of novel applications or to the knowledge of the mechanisms behind the known effects. One particular case is the alkaloid berberine, that was recently discovered by us to be a mitochondrially targeted alkaloid, inducing an arrest of proliferation in a murine melanoma cell line [32,33]. For the present study, we investigated whether SANG, an alkaloid similar to berberine, could also be cytotoxic for the same melanoma cell line. The K1735-M2 cell line is a 
Table 4 - Effects of SANG on succinate-energized mitochondria

\begin{tabular}{lccc} 
Protein $(\mathrm{nmol} / \mathrm{mg})$ & $\Delta \Psi(-\mathrm{mV})$ & ADP depolarization $(-\mathrm{mV})$ & Lag phase $(\mathrm{s})$ \\
\hline Control & $214.1 \pm 4.2$ & $28.8 \pm 4.2$ & $29.7 \pm 6.2$ \\
& $100 \pm 0.0 \%$ & $100 \pm 0.0 \%$ & $100 \pm 0.0 \%$ \\
0.7 & $209.0 \pm 3.3$ & $28.9 \pm 3.00$ & $36.6 \pm 5.3$ \\
& $98.8 \pm 2.5 \%$ & $100.3 \pm 1.0 \%$ & $26.4 \pm 3.4$ \\
1.3 & $213.0 \pm 3.6$ & $91.7 \pm 0.1 \%$ & $31.8 \pm 7.4$ \\
& $99.9 \pm 1.4 \%$ & $25.1 \pm 2.9$ & $107.2 \% \pm 0.1 \%$ \\
2.7 & $210.1 \pm 4.0$ & $88.7 \pm 5.4 \%$ & $33.0 \pm 7.2$ \\
& $98.6 \pm 1.5 \%$ & $20.7 \pm 2.7$ & $111.3 \pm 7.1 \%$ \\
5.3 & $202.6 \pm 2.8$ & $71.9 \pm 10.3 \%$ & $43.2 \pm 6.3$ \\
& $95.7 \pm 2.1 \%$ & $164.3 \pm 50.0 \%$
\end{tabular}

$\Delta \Psi \max , \mathrm{ADP}$ depolarization and lag phase was measured by using a $\mathrm{TPP}^{+}$-selective in the conditions of Table 2.

very invasive melanoma cell line and is considered a good model for metastatic melanoma [30,31].

In the present work, we demonstrate that SANG inhibits cell proliferation by causing cell death and an arrest of proliferation of K1375-M2 cells (Figs. 2 and 6). Another published work demonstrated that SANG causes G1 arrest in vascular smooth muscle cells [39] and a disruption of nucleocytoplasmic trafficking of cyclin D1 in breast cancer MCF-7 cells [20]. In the present study, a clear increase in subG1 peaks is observable, especially at 48 and $72 \mathrm{~h}$ of incubation with SANG, which suggests the occurrence of apoptosis. At the $24 \mathrm{~h}$ time point, a decrease in the proportion of cell in S phase may be due to heightened sensitivity of cells to actively replicating DNA to SANG-induced DNA damage, resulting in cell death. For the $48 \mathrm{~h}$ time point, it appears that for the highest SANG concentration, cells are dying regardless of the cell cycle phase. Finally, the data suggests that for $72 \mathrm{~h}$, cell death continues for lower concentrations. The much higher number of control cells in G1 phase when compared with other cell cycle phases for this time point results in an apparent higher sensitivity of cells in his cell cycle phase to SANG. Work is being carried out in our laboratories to identify alterations in key melanoma cell cycle checkpoints after treatment with SANG.

Table 5 - SANG effects on the mitochondrial ATPase activity evaluated by using two distinct methodologies

\begin{tabular}{lcc} 
& $\mathrm{nmol} \mathrm{H} / \mathrm{mg}$ protein & $\Delta \Psi(-\mathrm{mV})$ \\
\hline Control & $4.0 \pm 0.3$ & $167.4 \pm 1$ \\
& $100 \pm 0.0 \%$ & $100 \pm 0.0 \%$ \\
2.7 & $4.0 \pm 0.3$ & $167.1 \pm 1$ \\
& $100.5 \pm 2.1 \%$ & $99.8 \pm 0.4 \%$ \\
5.3 & $3.8 \pm 0.2$ & $167.8 \pm 1$ \\
& $94.2 \pm 1.0 \%$ & $100.2 \pm 0.2 \%$ \\
\hline
\end{tabular}

In freeze-thawed mitochondria, ATP hydrolysis induces variations in the $\mathrm{pH}$ medium which were followed by a $\mathrm{pH}$ electrode. Intact liver mitochondria generate $\Delta \Psi$ when ATP is added and respiration is inhibited. Data are presented as percentage of control. Control is expressed in absolute values. $\mathrm{nmol} \mathrm{H}^{+} / \mathrm{mg}$ protein and $\mathrm{mV}$. Values are means \pm S.E.M. of 4 different mitochondrial preparations. $p<0.05$ vs. control.
Table 6 - Mitochondrial swelling due to MPT pore opening

Amplitude (A.U.) Swelling rate (-A.U./min)

\begin{tabular}{|c|c|c|}
\hline Control & $\begin{array}{c}0.1 \pm 0.1 \\
100 \pm 0.0 \%\end{array}$ & $\begin{array}{l}0.02 \pm 0.0 \\
100 \pm 0.0 \%\end{array}$ \\
\hline 0.9 & $\begin{array}{c}0.1 \pm 0.1 \\
94.6 \pm 19.1 \%\end{array}$ & $\begin{aligned} 0.02 & \pm 0.0 \\
140.9 & \pm 37.8 \%\end{aligned}$ \\
\hline 1.8 & $\begin{aligned} 0.1 & \pm 0.1 \\
165.8 & \pm 60.5 \%\end{aligned}$ & $\begin{aligned} 0.02 & \pm 0.0 \\
142.8 & \pm 37.8 \%\end{aligned}$ \\
\hline 3.6 & $\begin{array}{c}0.2 \pm 0.1 \\
258.6 \pm 74.5 \%\end{array}$ & $\begin{aligned} 0.03 & \pm 0.0 \\
224.1 & \pm 67.3 \%\end{aligned}$ \\
\hline 7.2 & $\begin{aligned} 0.2 & \pm 0.1 \\
249.6 & \pm 51.9 \%\end{aligned}$ & $\begin{aligned} 0.03 & \pm 0.0 \\
194.9 & \pm 30.3 \%\end{aligned}$ \\
\hline 14.4 & $\begin{array}{c}0.4 \pm 0.1 \\
424.2 \pm 91.1^{*}\end{array}$ & $\begin{array}{c}0.04 \pm 0.01 \\
344.5 \pm 57.2 \%\end{array}$ \\
\hline $14.4 \pm$ CyclA & $\begin{array}{l}0.06 \pm 0.0 \\
78.2 \pm 30.2 \%^{\dagger}\end{array}$ & $\begin{array}{l}0.01 \pm 0.1 \\
64.8 \pm 27.6 \%^{\dagger}\end{array}$ \\
\hline
\end{tabular}

Evaluated parameters were studied by measuring light dispersion changes in the mitochondrial preparation at $540 \mathrm{~nm}$. Amplitude was calculated as the difference between basal line absorbance and the absorbance registered $500 \mathrm{~s}$ after calcium addition. Rate values represent the initial mitochondrial swelling rate after the addition of calcium ( $60 \mathrm{~s}$ after the beginning of the experiment). Data are means \pm S.E.M. of at least four different experiments.

$p<0.05$ vs. control.

$p<0.05$ vs. $\mathrm{Ca}^{2+} \pm 14.4 \mathrm{nmol} \mathrm{SANG} / \mathrm{mg}$ protein.

The data obtained also indicates that SANG kills K1735-M2 cells by apoptosis, as measured by caspase activation (Fig. 7). The results also confirms that SANG is highly effective in killing the invasive K1735-M2 cell line since it is effective below $10 \mu \mathrm{M}$. Interestingly, when FCCP was pre-incubated with K1735-M2 cells, the cytotoxicity of SANG was increased for one of the concentrations tested (Fig. 2). The result may indicate that for that precise concentration, SANG and FCCP may act in different targets. Another interesting hypothesis is that the decrease in the levels of ATP caused by FCCP, as described previously [32], would increase the cytotoxicity of SANG by inhibiting the activity of the multi-resistance drug protein responsible for the efflux of chemotherapeutic agents [45]. 


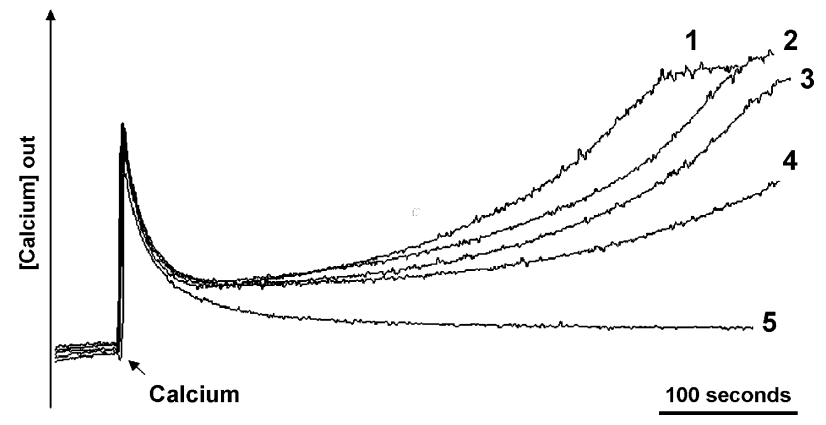

Fig. 10 - Evaluation of mitochondrial calcium loading. SANG was incubated with mitochondria $(0.4 \mathrm{mg})$ in the following concentrations: (1) $2.5 \mathrm{nmol} / \mathrm{mg}$ protein, (2) $1.25 \mathrm{nmol} / \mathrm{mg}$ protein, (4) $5 \mathrm{nmol} / \mathrm{mg}$ protein, (5) $2.5 \mathrm{nmol}$ SANG/mg protein in the presence of Cyclosporin A (100 nM). Line 3: Control (no SANG). The fluorescent probe Calcium Green 5-N (100 nM) was used to follow extramitochondrial calcium variations.

As previously described for MCF-7 cells [20], SANG is accumulated by the nuclei of K1735-M2 cells (Fig. 3). Using epifluorescence microscopy and using SANG self-fluorescence, a larger nuclear to mitochondrial ratio of SANG accumulation was detected (Fig. 3), this despite the similarity in structure with berberine, an alkaloid that is accumulated by polarized mitochondria [32]. One possible explanation for the differential accumulation may be that the positive moiety in SANG is less polar due to the existence of a methyl group linked with the nitrogen atom. By using flow cytometry, a direct relationship between drug concentration and cell fluorescence was obtained, indicating that SANG is accumulated by cells most likely by passive diffusion (Fig. 3). No plateau in cell fluorescence was obtained even for concentrations of SANG that were much higher than the ones used in the present study. Although not measured in the present study, Holy et al. [20] demonstrated that nuclear accumulation of SANG decreases after a few hours, which may suggest localization to other intracellular targets as mitochondria, although further studies are needed to assess if SANG can exist in other extra-nuclear organelles in a nonfluorescent form.

SANG was found to cause the rounding up of cells and chromatin condensation, which are typical signs of apoptosis [46]. Another interesting finding was that SANG causes a mixed effect on mitochondrial polarization (Fig. 4L). A complete lack of TMRM signalling was found inside some living cells, in contrast with other cells in the same field of view, which showed clear, although weaker than control, TMRM labelling. An association between mitochondrial depolarization and increased oxidative stress was not found for 6 and $24 \mathrm{~h}$ (Fig. 5), although it has been previously that the release of cytochrome c can in some circumstances increase superoxide production by the respiratory chain [47].

An attractive possibility is that mitochondrial depolarization could be associated with nuclear DNA damage, already identified in other tumour cell lines $[19,48]$. DNA damage can lead to the activation of p53 [49], which would lead to several biological effects among which the expression of pro- apoptotic proteins such as Bax and APAF-1 [49]. Both Bax and $\mathrm{p} 53$ can be translocated to mitochondria, with Bax forming channels in the outer mitochondrial membrane through where pro-apoptotic proteins enclosed in the intermembrane space can be released. The role of p53 translocation to mitochondria is not as clear. Some researchers have proposed that the mitochondrial translocation of p53 can act to cause cell death or to protect the mitochondrial genome during several aggressions [50,51]. Because of this, one initial hypothesis would be that mitochondrial depolarization would be a consequence of $\mathrm{Bax}$ and/or p53 translocation to mitochondria. Western blotting assays demonstrated that SANG induces an increase in p53 concentration in both total cell extracts and mitochondrial fractions, but no Bax upregulation was found in total cells extracts (Fig. 8). Nevertheless, it would still be possible that selective accumulation of Bax in mitochondria would occur. However, Western blotting did not indicate that Bax translocation to mitochondria occurred (Fig. 8). We also performed Western blotting against APAF, a downstream target of $\mathrm{p} 53$ and again, quantitative increases in either whole-cell or mitochondrial preparations were not observed (Fig. 8) Although further work is necessary, it is possible that K1735-M2 do not respond to p53-mediated apoptotic stimuli due to mutations on the p53 binding site or in the protein itself.

A final explanation for mitochondrial SANG effects would be a direct effect on the bioenergetic apparatus of such organelles. To test this possibility, experiments on isolated hepatic fractions were conducted. Although differences exist between mitochondria from normal and tumour cells, the basic machinery for energy production is the same. It was also difficult to obtain a good mitochondrial isolation yield from K1735-M2 cells in order to perform all the necessary experiments. Because of these reasons, we tested the effects of sanguinarine on isolated hepatic mitochondrial fractions in the same context as in previous studies [32]. In the range of SANG concentrations used in cells, we observed that SANG, for the highest concentrations tested, inhibited uncoupled and state 3 respiration, although no negative effects were observed in the ADP/O ratio and only very minor effects were observed in the activity of the ATPase (Tables 1, 2 and 5). The effects occurred for substrates for both complexes I and II, although they were more prominent for complex I substrates (Table 1). The results indicate that SANG inhibits mostly the respiratory chain and not the phosphorylative system, since most endpoints of activity of the former were not affected. Stimulated state 4 or state 4 plus oligomycin respiration also suggests proton permeabilization through the membrane or a decoupling effect on the components of the respiratory chain (Figs. 1 and 2). The most interesting results arise from measurements of the MPT pore activity (Fig. 6). When measuring mitochondrial swelling, no increased swelling rate or amplitude occurred after calcium addition in the presence of SANG, except when a high concentration of the compound was used. For concentrations of SANG in the same range as the ones used in cells, not only no increased swelling due to MPT pore opening occurred, as SANG appeared to have a mixed type of effect according to the concentration when directly measuring calcium accumulation (Fig. 10). For lower concentrations, SANG consistently decreased calcium loading capacity but 
increased calcium uptake for the largest concentrations tested (Fig. 10). One possible explanation for this behaviour would be that SANG would decrease mitochondrial $\Delta \Psi$ for the highest concentrations, thus decreasing calcium entry and hence pore opening but measurements of $\Delta \Psi$ using a TPP-selective electrode excluded this hypothesis. Another likely explanation is that SANG can act as an antioxidant [52,53], effective for the highest concentrations tested, thus inhibiting pore opening by reducing the amount of oxidized thiol groups in the pore complex [54]. The differential activity of SANG on calcium loading capacity (Fig. 10) invites to at least a partly explanation regarding the effects of SANG on mitochondrial polarization of intact melanoma cells. As we cannot exclude that SANG, even if in lower amounts, can accumulate in mitochondria after its peak on nuclear accumulation (see above), an attractive hypothesis is that SANG, by achieving different concentrations in mitochondria can activate or inhibit MPT pore induction. The activation would lead to mitochondrial depolarization, while hardly any effect would be seen by SANG inhibition of pore openings in situ. Activation of caspase 9 (Fig. 7) is an indication of the involvement of the intrinsic pathway for apoptosis. In fact, induction of the MPT pore in situ could lead to rupture of the mitochondrial outer membrane and escape of pro-apoptotic proteins including cytochrome c, thus activating the mitochondrial pathway for apoptosis [55].

The true purpose of the present work was to identify the mechanisms of cell death induced by SANG. The results here shown demonstrate that SANG causes apoptosis for micromolar concentrations on an invasive metastatic melanoma cell line, which involves caspase 9 and 3 activation. The data indicates that in opposition to other tumour cell lines [21,56], SANG does not increase Bax levels in K1735-M2 melanoma cells. A similar result was obtained in human CEM T-leukemia cells [26]. The interesting result was that the absence of Bax over-expression occurred with an increase of p53 protein. Matkar et al. [19] demonstrated that SANG-induced death in human colon cancer cells was p53-independent, although DNA damage was detected in K1735-M2 cells.

The results suggest that mitochondrial depolarization induced by SANG is associated with nuclear DNA damage, although it may not exclusively result from pathways activated by the latter event. Other factors such as direct effects of the drug on the organelle after initial nuclear effects can also account for mitochondrial dysfunction and lead cells to die upon caspase activation despite the fact that the p53Bax pathway is not operating. The data presented suggest that SANG acts as a DNA damaging agent, showing also collateral damage to mitochondrial bioenergetics, in a fashion similar to doxorubicin, a powerful anti-cancer agent which acts both at the mitochondrial and nuclear level [57]. SANG should be considered as a potential novel chemotherapeutic for the treatment of aggressive melanoma, with further tests required to identify potential advantages of combinations with other molecules.

\section{Acknowledgments}

The present work was funded by the Portuguese Foundation for Science and Technology (FCT), research grant PTDC/SAU/
OSM/64084/2006. FCT also supported TLS (Ph.D. fellowship SFRH/BD/38067/2007), VAS (Pos-Doc fellowship SFRH/BPD/ 31549/2006), GCP (Ph.D. fellowship SFRH/BD/36938/2007), AFB (Ph.D. fellowship SFRH/BD/41384/2007) and SLP (Ph.D. fellowship SFRH/BD/37933/2007).

\section{R E F E R E N C E S}

[1] Dyke SF, Moon BJ, Sainsbury M. The synthesis of sanguinarine. Tetrahedron Lett 1968;36:3933-4.

[2] Mackraj I, Govender T, Gathiram P. Sanguinarine. Cardiovasc Ther 2008;26:75-83.

[3] Pi G, Ren P, Yu J, Shi R, Yuan Z, Wang C. Separation of sanguinarine and chelerythrine in Macleaya cordata (Willd) $\mathrm{R}$. Br. based on methyl acrylate-co-divinylbenzene macroporous adsorbents. J Chromatogr A 2008;1192: 17-24.

[4] Baker K. Mouthrinses in the prevention and treatment of periodontal disease. Curr Opin Periodontol 1993; 89-96.

[5] Balanyk TE. Sanguinarine: comparisons of antiplaque/ antigingivitis reports. Clin Prev Dent 1990;12:18-25.

[6] Allen CM. Viadent-related leukoplakia-the tip of the iceberg? Oral Surg Oral Med Oral Pathol Oral Radiol Endod 1999;87:393-4.

[7] Anderson KM, Stoner GD, Fields HW, Chacon GE, Dohar AL, Gregg BR, et al. Immunohistochemical assessment of Viadent-associated leukoplakia. Oral Oncol 2005;41:200-7.

[8] Godowski KC. Antimicrobial action of sanguinarine. J Clin Dent 1989;1:96-101.

[9] Giuliana G, Pizzo G, Milici ME, Musotto GC, Giangreco R. In vitro antifungal properties of mouthrinses containing antimicrobial agents. J Periodontol 1997;68:729-33.

[10] Dvorak Z, Vrzal R, Maurel P, Ulrichova J. Differential effects of selected natural compounds with anti-inflammatory activity on the glucocorticoid receptor and NF-kappaB in HeLa cells. Chem Biol Interact 2006;159:117-28.

[11] Kaminskyy V, Lin KW, Filyak Y, Stoika R. Differential effect of sanguinarine, chelerythrine and chelidonine on DNA damage and cell viability in primary mouse spleen cells and mouse leukemic cells. Cell Biol Int 2008;32: 271-7.

[12] Malikova J, Zdarilova A, Hlobilkova A, Ulrichova J. The effect of chelerythrine on cell growth, apoptosis, and cell cycle in human normal and cancer cells in comparison with sanguinarine. Cell Biol Toxicol 2006;22:439-53.

[13] Kemeny-Beke A, Aradi J, Damjanovich J, Beck Z, Facsko A, Berta A, et al. Apoptotic response of uveal melanoma cells upon treatment with chelidonine, sanguinarine and chelerythrine. Cancer Lett 2006;237:67-75.

[14] Vavreckova C, Gawlik I, Muller K. Benzophenanthridine alkaloids of Chelidonium majus. I: Inhibition of 5- and 12lipoxygenase by a non-redox mechanism. Planta Med 1996;62:397-401.

[15] Kuznetsova LP, Nikol'skaia EB, Sochilina EE, Faddeeva MD. Inhibition by various alkaloids of acetylcholinesterase and butyrylcholinesterase from human blood. Zh Evol Biokhim Fiziol 2002;38:28-31.

[16] Faddeeva MD, Beliaeva TN. Inhibition of the activity of membrane-bound $\mathrm{Ca}^{2+}$-ATPase in the sarcoplasmic reticulum fragments of rabbit skeletal muscles by the alkaloid sanguinarine. Tsitologiia 1988;30:685-90.

[17] Seifen E, Adams RJ, Riemer RK. Sanguinarine: a positive inotropic alkaloid which inhibits cardiac $\mathrm{Na}^{+}, \mathrm{K}^{+}$-ATPase. Eur J Pharmacol 1979;60:373-7. 
[18] Lopus M, Panda D. The benzophenanthridine alkaloid sanguinarine perturbs microtubule assembly dynamics through tubulin binding. A possible mechanism for its antiproliferative activity. FEBS J 2006;273: 2139-50.

[19] Matkar SS, Wrischnik LA, Hellmann-Blumberg U. Sanguinarine causes DNA damage and p53-independent cell death in human colon cancer cell lines. Chem Biol Interact 2008;172:63-71.

[20] Holy J, Lamont G, Perkins E. Disruption of nucleocytoplasmic trafficking of cyclin D1 and topoisomerase II by sanguinarine. BMC Cell Biol 2006;7:13.

[21] Adhami VM, Aziz MH, Mukhtar H, Ahmad N. Activation of prodeath Bcl-2 family proteins and mitochondrial apoptosis pathway by sanguinarine in immortalized human HaCaT keratinocytes. Clin Cancer Res 2003;9: 3176-82.

[22] Jeong SY, Seol DW. The role of mitochondria in apoptosis. BMB Rep 2008;41:11-22.

[23] Han SI, Kim YS, Kim TH. Role of apoptotic and necrotic cell death under physiologic conditions. BMB Rep 2008;41:1-10.

[24] Ralph SJ, Low P, Dong L, Lawen A, Neuzil J. Mitocans: mitochondrial targeted anti-cancer drugs as improved therapies and related patent documents. Recent Patents Anticancer Drug Discov 2006;1:327-46.

[25] Barreto MC, Pinto RE, Arrabaca JD, Pavao ML. Inhibition of mouse liver respiration by Chelidonium majus isoquinoline alkaloids. Toxicol Lett 2003;146:37-47.

[26] Kaminskyy V, Kulachkovskyy O, Stoika R. A decisive role of mitochondria in defining rate and intensity of apoptosis induction by different alkaloids. Toxicol Lett 2008;177: 168-81.

[27] Hussain AR, Al-Jomah NA, Siraj AK, Manogaran P, AlHussein K, Abubaker J, et al. Sanguinarine-dependent induction of apoptosis in primary effusion lymphoma cells. Cancer Res 2007;67:3888-97.

[28] Ivanov VN, Bhoumik A, Ronai Z. Death receptors and melanoma resistance to apoptosis. Oncogene 2003;22: 3152-61.

[29] Helmbach H, Rossmann E, Kern MA, Schadendorf D. Drugresistance in human melanoma. Int J Cancer 2001;93: 617-22.

[30] Repesh LA, Drake SR, Warner MC, Downing SW, Jyring R, Seftor EA, et al. Adriamycin-induced inhibition of melanoma cell invasion is correlated with decreases in tumor cell motility and increases in focal contact formation. Clin Exp Metastasis 1993;11:91-102.

[31] Repesh LA. A new in vitro assay for quantitating tumor cell invasion. Invasion Metastasis 1989;9:192-208.

[32] Pereira GC, Branco AF, Matos JA, Pereira SL, Parke D, Perkins EL, et al. Mitochondrially targeted effects of berberine [Natural Yellow 18, 5,6-dihydro-9,10dimethoxybenzo(g)-1,3-benzodioxolo(5,6-a) quinolizinium] on K1735-M2 mouse melanoma cells: comparison with direct effects on isolated mitochondrial fractions. J Pharmacol Exp Ther 2007;323:636-49.

[33] Serafim TL, Oliveira PJ, Sardao VA, Perkins E, Parke D, Holy $J$. Different concentrations of berberine result in distinct cellular localization patterns and cell cycle effects in a melanoma cell line. Cancer Chemother Pharmacol 2008;61:1007-18.

[34] Rasola A, Bernardi P. The mitochondrial permeability transition pore and its involvement in cell death and in disease pathogenesis. Apoptosis 2007;12:815-33.

[35] Kroemer G, Galluzzi L, Brenner C. Mitochondrial membrane permeabilization in cell death. Physiol Rev 2007;87: 99-163.
[36] Lin ZX, Hoult JR, Raman A. Sulphorhodamine B assay for measuring proliferation of a pigmented melanocyte cell line and its application to the evaluation of crude drugs used in the treatment of vitiligo. J Ethnopharmacol 1999;66:141-50.

[37] Thundathil J, Filion F, Smith LC. Molecular control of mitochondrial function in preimplantation mouse embryos. Mol Reprod Dev 2005;71:405-13.

[38] Sardao VA, Oliveira PJ, Holy J, Oliveira CR, Wallace KB. Vital imaging of H9c2 myoblasts exposed to tertbutylhydroperoxide-characterization of morphological features of cell death. BMC Cell Biol 2007;8:11.

[39] Lee B, Lee SJ, Park SS, Kim SK, Kim SR, Jung JH, et al. Sanguinarine-induced G1-phase arrest of the cell cycle results from increased p27KIP1 expression mediated via activation of the Ras/ERK signaling pathway in vascular smooth muscle cells. Arch Biochem Biophys 2008;471: 224-31.

[40] James D, Parone PA, Terradillos O, Lucken-Ardjomande S, Montessuit S, Martinou JC. Mechanisms of mitochondrial outer membrane permeabilization. Novartis Found Symp 2007;287:170-6. discussion 6-82.

[41] Yoshida T, Tomioka I, Nagahara T, Holyst T, Sawada M, Hayes $\mathrm{P}$, et al. Bax-inhibiting peptide derived from mouse and rat Ku70. Biochem Biophys Res Commun 2004;321: 961-6.

[42] Bombrun A, Gerber P, Casi G, Terradillos O, Antonsson B, Halazy S. 3,6-dibromocarbazole piperazine derivatives of 2propanol as first inhibitors of cytochrome c release via Bax channel modulation. J Med Chem 2003;46:4365-8.

[43] Kao J, Milano MT, Javaheri A, Garofalo MC, Chmura SJ, Weichselbaum RR, et al. gamma-H2AX as a therapeutic target for improving the efficacy of radiation therapy. Curr Cancer Drug Targets 2006;6:197-205.

[44] Mitscher LA, Drake S, Gollapudi SR, Okwute SK. A modern look at folkloric use of anti-infective agents. J Nat Prod 1987;50:1025-40.

[45] Shukla S, Wu CP, Ambudkar SV. Development of inhibitors of ATP-binding cassette drug transporters: present status and challenges. Expert Opin Drug Metab Toxicol 2008;4:205-23.

[46] Hall PA. Assessing apoptosis: a critical survey. Endocr Relat Cancer 1999;6:3-8.

[47] Ott M, Gogvadze V, Orrenius S, Zhivotovsky B. Mitochondria, oxidative stress and cell death. Apoptosis 2007;12:913-22.

[48] Ansari KM, Dhawan A, Khanna SK, Das M. In vivo DNA damaging potential of sanguinarine alkaloid, isolated from argemone oil, using alkaline Comet assay in mice. Food Chem Toxicol 2005;43:147-53.

[49] Meulmeester E, Jochemsen AG. p53: a guide to apoptosis. Curr Cancer Drug Targets 2008;8:87-97.

[50] Moll UM, Zaika A. Nuclear and mitochondrial apoptotic pathways of p53. FEBS Lett 2001;493:65-9.

[51] Nithipongvanitch R, Ittarat W, Velez JM, Zhao R, St Clair DK, Oberley TD. Evidence for p53 as guardian of the cardiomyocyte mitochondrial genome following acute adriamycin treatment. J Histochem Cytochem 2007;55: 629-39.

[52] Das A, Mukherjee A, Chakrabarti J. Sanguinarine: an evaluation of in vivo cytogenetic activity. Mutat Res 2004;563:81-7.

[53] Firatli E, Unal T, Onan U, Sandalli P. Antioxidative activities of some chemotherapeutics. A possible mechanism in reducing gingival inflammation. J Clin Periodontol 1994;21:680-3.

[54] Halestrap AP, Woodfield KY, Connern CP. Oxidative stress, thiol reagents, and membrane potential modulate the mitochondrial permeability transition by affecting 
nucleotide binding to the adenine nucleotide translocase. J Biol Chem 1997;272:3346-54.

[55] Grimm S, Brdiczka D. The permeability transition pore in cell death. Apoptosis 2007;12:841-55.

[56] Weerasinghe P, Hallock S, Tang SC, Liepins A. Role of $\mathrm{Bcl}-2$ family proteins and caspase- 3 in sanguinarine- induced bimodal cell death. Cell Biol Toxicol 2001;17: 371-81.

[57] Kiyomiya K, Matsuo S, Kurebe M. Differences in intracellular sites of action of Adriamycin in neoplastic and normal differentiated cells. Cancer Chemother Pharmacol 2001;47:51-6. 